\title{
Emergence of a Novel Reassortant H5N3 Avian Influenza Virus in Korean Mallard Ducks in 2018
}

\author{
Seon-Ju Yeo ${ }^{a}$ Vui Thi Hoang ${ }^{b}$ Tuan Bao Duong ${ }^{b}$ Ngoc Minh Nguyen ${ }^{b}$ \\ Hien Thi Tuong ${ }^{b}$ Mudsser Azam ${ }^{b}$ Haan Woo Sung ${ }^{c}$ Hyun Park $^{b}$ \\ aDepartment of Tropical Medicine and Parasitology, Seoul National University College of Medicine, Seoul, \\ Republic of Korea; bepartment of Infection Biology, Zoonosis Research Center, School of Medicine, Wonkwang \\ University, Iksan, Republic of Korea; 'College of Veterinary Medicine, Kangwon National University, Chuncheon, \\ Republic of Korea
}

\section{Keywords}

Avian influenza $\cdot$ H5N3 subtype $\cdot$ Low-pathogenic virus .

Novel reassortment

\begin{abstract}
Introduction: The avian influenza (Al) virus causes a highly contagious disease which is common in wild and domestic birds and sporadic in humans. Mutations and genetic reassortments among the 8 negative-sense RNA segments of the viral genome alter its pathogenic potential, demanding well-targeted, active surveillance for infection control. Methods: Wild duck fecal samples were collected during the 2018 bird health annual surveillance in South Korea for tracking variations of the $\mathrm{Al}$ virus. One low-pathogenic avian influenza $\mathrm{H} 5 \mathrm{~N} 3$ reassortment virus (A/mallard duck/South Korea/ KNU18-91/2018 [H5N3]) was isolated and genomically characterized by phylogenetic and molecular analyses in this study. Results: It was devoid of polybasic amino acids at the hemagglutinin ( $\mathrm{HA})$ cleavage site and exhibited a stalk region without deletion in the neuraminidase (NA) gene and NA inhibitor resistance-linked E/D627K/N and D701N marker mutations in the $P B 2$ gene, suggesting its low-pathogenic
\end{abstract}

Al. It showed a potential of a reassortment where only $H A$ originated from the $\mathrm{H} 5 \mathrm{~N} 3$ poultry virus of China and other genes were derived from Mongolia. In phylogenetic analysis, $\mathrm{HA}$ was different from that of the isolate of H5N3 in Korea, 2015. In addition, this novel virus showed adaptation in Madin-Darby canine kidney cells, with $8.05 \pm 0.14 \log 1050 \%$ tissue culture infectious dose (TCID50) $/ \mathrm{mL}$ at $36 \mathrm{~h}$ postinfection. However, it could not replicate in mice well, showing positive growth at 3 days postinfection (dpi) $(2.1 \pm 0.13 \log 10$ TCID50/mL) but not at 6 dpi. Conclusions: The HA antigenic relationship of A/mallard duck/South Korea/KNU18-91/2018 (H5N3) showed differences toward one of the old low-pathogenic H5N3 viruses in Korea. These results indicated that a novel reassortment low-pathogenic avian influenza H5N3 subtype virus emerged in South Korea in 2018 via novel multiple reassortments with Eurasian viruses, rather than one of old Korean H5N3 strains.

(c) 2021 The Author(s).

Published by S. Karger AG, Basel

Seon-Ju Yeo, Vui Thi Hoang, and Tuan Bao Duong contributed equally to this manuscript.
C 2021 The Author(s).

Published by S. Karger AG, Basel

This is an Open Access article licensed under the Creative Commons Attribution-NonCommercial-4.0 International License (CC BY-NC) (http://www.karger.com/Services/OpenAccessLicense), applicable to the online version of the article only. Usage and distribution for commercial purposes requires written permission.
Correspondence to:

Haan Woo Sung, sunghw@ kangwon.ac.kr

Hyun Park, hyunpk@wku.ac.kr 


\section{Introduction}

Mallard ducks are major contributors to the evolution, maintenance, and spread of avian influenza viruses (AIVs). Waterfowl, including ducks, geese, terns, shorebirds, and swans, are known to host all 16 hemagglutinin (HA) and 9 neuraminidase (NA) subtypes of influenza A viruses (H1718 and N10-11 subtypes were identified in bats) [1-4]. Live infected birds with low-pathogenic avian influenza (LPAI) viruses are often asymptomatic or display subclinical symptoms, enabling viral hosting over multiple seasons and viral spreading over long distances with host migration. Infected birds shed large amounts of viruses in their excretions and therefore pose the highest risk for virus transmission through direct or indirect contact with other healthy birds, mammals, and possibly humans [4].

The H5N3 viruses were first detected in South Africa in 1959 and are endemic in aquatic birds, especially wild and domestic ducks. Several other $\mathrm{H} 5$ subtypes, including H5N1, H5N2, H5N6, H5N7, and H5N8, have been detected in wild and domestic aquatic birds, and co-infections are a potential threat to both the poultry industry and public health $[5,6]$. In South Korea, a high pathogenic avian influenza (HPAI) H5 subtype (H5N8) outbreak was observed in 2014 and its epidemiological analysis suggested it was associated with migratory birds [7]. As the co-circulation of LPAI, H5N3, and HPAI H5 subtypes in a region may facilitate the emergence of new viral reassortments with new genotypes, continuous surveillance of $\mathrm{H} 5 \mathrm{~N} 3$ is needed for migratory birds in South Korea.

From 2012 to 2014, LPAI H5N3 viruses have been detected among wild birds in South Korea where the $H A$ gene is clustered with previous South Korean isolates of Eurasian origin [8]. In the same study, the H5N8 subtype isolated from a live bird market belonged to the $\mathrm{H} 5$ clade 2.3.4.4 and was confirmed as an HPAI virus with multiple basic amino acid sequences at the HA cleavage site. Although H5N3 has not been reported in South Korea since 2017, H5N3 reassortments have been isolated and characterized from migratory waterfowl in 2018 in Jiangsu Province, China [9], and the geographic location and shared migratory bird flyway are increasing concern regarding the introduction of new subtypes from migratory birds passing through South Korea. The East Asian-Australasian flyway is one of the main migratory flyways, and the Korean Peninsula region is an important stopover point along this route [10].

Due to growing concerns over emerging genotypes and the pandemic potential of recently reassorted $\mathrm{H} 5$ AIVs imported to South Korea, genetic and phylogenic analyses of an H5 AIV isolated from the mallard duck in South Korea in 2018 were performed in the present study to verify its pathogenicity.

\section{Materials and Methods}

\section{Virus Isolation}

During the annual surveillance of bird health, fecal samples from mallard birds were collected in different regions of South Korea from January to December 2018. Feces were resuspended in antibiotic containing $1 \times$ phosphate-buffered saline (PBS), and the supernatant was filtered and then inoculated in 9-day-old specific pathogen-free embryonated chicken eggs (ECEs) for virus isolation. Allantoic fluid was collected from the inoculated ECEs at 72 $\mathrm{h}$ after inoculation, and the hemagglutination assay was performed with $1 \%$ packed chicken red blood cells, according to the World Organization for Animal Health recommendations [11].

\section{Reverse Transcription PCR and Sequencing}

Viral RNA was extracted directly from the allantoic fluid of ECEs using a total RNA extraction kit (Macherey-Nagel, South Korea) according to the manufacturer's instructions, with minor modifications. In brief, the virus-containing egg fluid was mixed with lysis buffer containing $\beta$-mercaptoethanol. The viscosity of the suspension was reduced using the NucleoSpin filter provided in the kit, and the RNA-binding conditions were adjusted by adding ethanol. The solubilized RNA was bound to the NucleoSpin RNA column membrane provided in the kit, and desalting was performed by adding the membrane desalting buffer. The DNA digestion step was omitted because rDNase treatment reduced RNA stability. Elution was performed directly after washing the desalted membrane with the wash buffers. First-strand cDNA was then transcribed using the SuperScript III first-strand cDNA synthesis kit (Invitrogen, Waltham, MA, USA) using a universal primer for influenza A virus (Uni12-AGCRAAAGCAGG) in a final volume of $20 \mu \mathrm{L}$, as per the manufacturer's protocol.

To evaluate the AIV growth and determine its subtype, conventional RT-PCR for influenza A virus was performed using total RNA, following the World Health Organization guidelines [12]. Host identification was confirmed by DNA barcoding using a 648bp region of the cytochrome c oxidase I mitochondrial gene, as previously described [13].

\section{Next-Generation Sequencing on Illumina Hiseq X}

Next-generation sequencing was conducted by GnCBIO (DaeJeon, South Korea) on the Illumina Hiseq X platform (Illumina Inc., Foster City, CA, USA), as previously reported [14]. In brief, viral RNA quality was determined using an Agilent RNA 6000 Pico kit (Agilent Technologies Inc., Santa Clara, CA, USA), and its concentration was measured using a spectrophotometer. The cDNA library of viral RNA was determined using a QIAGEN (Germany) QIAseq FX single-cell RNA library kit. Library concentration was measured by LightCycler qPCR (Roche, Switzerland), and library size was checked using the TapeStation HS D5000 screen tape (Agilent Technologies Inc.). For cluster generation, the library was loaded into a flow cell where fragments were captured on a lawn of surface-bound oligos complementary to the library adapters. Each fragment was then amplified into distinct and clonal clusters 
using bridge amplification. When cluster generation was complete, the templates were ready for sequencing. Sequencing data were converted into raw data for analysis.

Raw sequence reads were quality-trimmed using "Trim_Galore" $(q=20)$, and non-influenza virus reads were removed using Deconseq (iden $=60$ ). A Python script was used to adjust the amount of data up to 600,000 reads. A database containing only segments $4 \mathrm{HA}, 6 \mathrm{NA}$, and 8 nonstructural (NS1) of influenza viruses deposited in the National Center for Biotechnology Information (NCBI) database was generated and aligned to those of the reference AIVs using Gsmapper (iden $=70, \mathrm{~mL}=40$ ). The open reading frame (ORF) was found using the obtained consensus and its similarity to reference AIVs ORFs. As the ORF length differed from that of the reference viruses, sequence error was corrected using Proovread, as previously described [15].

\section{Molecular Characterization and Phylogenetic Analysis}

The basic local alignment search tool of the NCBI was used to identify relevant AIV genes, and reference viral sequences were downloaded from the NCBI database. The amino acid sequences of 8 gene segments were deduced from the obtained AIV nucleotide sequences using MEGA 6.0 [16]. Multiple sequence alignment and phylogenetic analysis were also conducted using MEGA 6.0.

Phylogenetic trees for the 8 gene segments (polymerase basic 2[ $P B 2]$; polymerase basic 1[ $P B 1]$; polymerase acidic [PA]; HA; nucleoprotein[ $N P]$; neuraminidase[ $N A]$; matrix [M]; and $N S$ ) of $\mathrm{H} 5 \mathrm{~N} 3$ were generated using the neighbor-joining method, Kimura's twoparameter distance model, and 1,000 bootstrap replicates [16]. The $H A$ and NA gene trees included sequences with high homology in the NCBI database, the H5N3 subtype reported from South Korea (complete genome), and a representative H5 HPAI strain. The trees for the other 6 internal segments ( $P B 2, P B 1, P A, N P, M$, and $N S$ ) included influenza virus isolates with nucleotide homologies to respective segments from different geographic regions.

\section{Determination of Infectious Doses}

The enzyme-linked immunosorbent assay was used to measure the $50 \%$ tissue culture infectious dose (TCID50) titers as previously reported [17]. Madin-Darby canine kidney (MDCKs) cells were grown on the flat-bottom 96 -well plates under $37^{\circ} \mathrm{C}$ and $5 \%$ $\mathrm{CO}_{2}$ conditions. When MDCK cell confluence reached $80-90 \%$, cells were washed with $1 \times$ PBS and then inoculated with serial 10fold dilutions of virus suspensions. Inoculated cells were incubated under $37^{\circ} \mathrm{C}$ and $5 \% \mathrm{CO}_{2}$ for 3 days, and the TCID50 titers were determined using the Reed and Muench method [18].

The growth kinetics of a novel isolate (A/mallard duck/South Korea/KNU18-91/2018 (H5N3) (KNU18-91), SBD/Korea/KNU SYG06/06 (H5N3), and A/California/04-005 MA/2009 (H1N1) (A/California/04/2009 (H1N1) viruses were evaluated in vitro. The viruses were inoculated to MDCK cells at a multiplicity of infection of 0.01 using Dulbecco's modified Eagle medium containing $1 \mu \mathrm{g} / \mathrm{mL} \mathrm{L}$-1-tosylamide-2-phenylethylchloromethylketonetreated trypsin. Supernatants were collected at 12, 24, 36, 48, 60, and $72 \mathrm{~h}$ postinfection (hpi). The TCID50 of each supernatant was determined in MDCK cells [19].

To measure the $50 \%$ egg infective dose (EID50), the chorioallantoic cavities of 10-day-old specific pathogen-free, ECEs were inoculated with $100 \mu \mathrm{L}$ serial 10 -fold dilutions of the viruses, using 5 ECEs for each dilution. The ECEs were incubated at $37^{\circ} \mathrm{C}$ for 3 days, after which the allantoic fluid was harvested and tested for
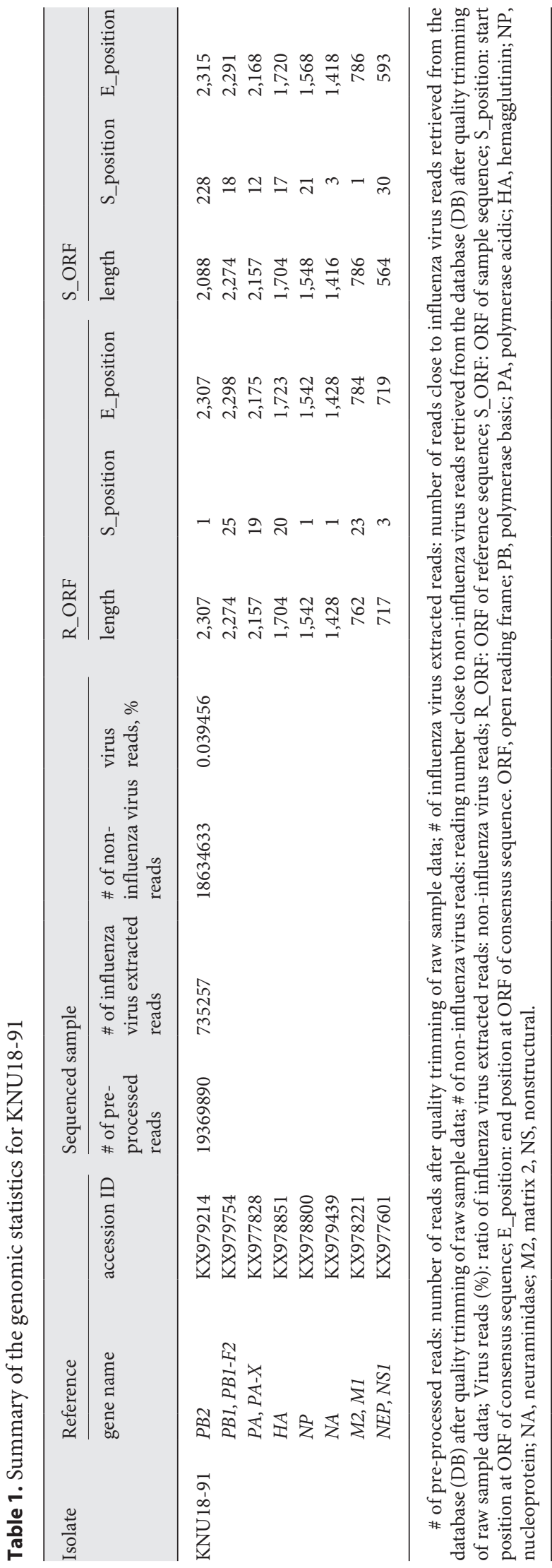

Isolation of New Avian Influenza Virus (H5N3) in Duck
Intervirology 2022;65:1-16 DOI: $10.1159 / 000517057$ 


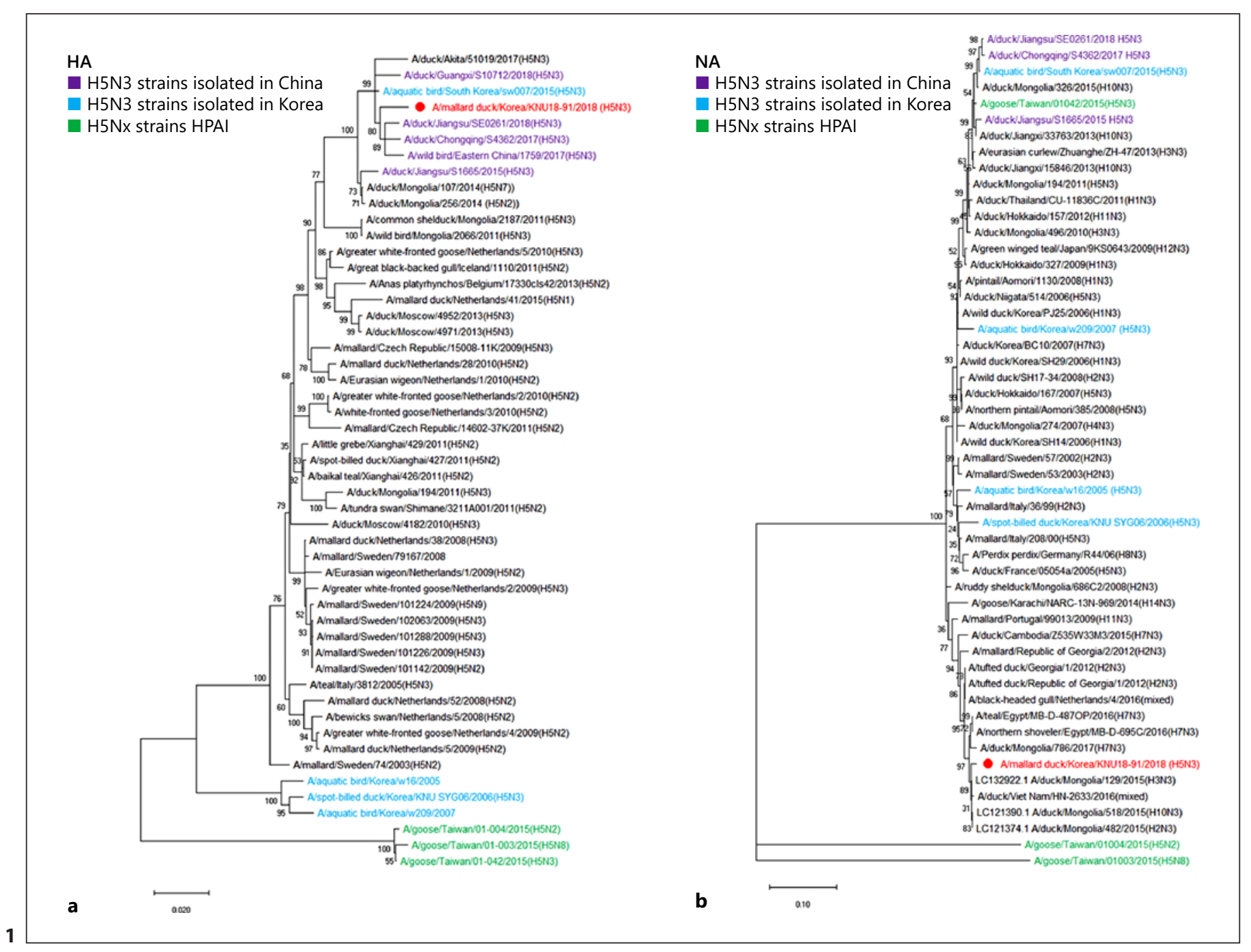

(Figure continued on next pages.)

the hemagglutination activity [11]. Calculation of EID50 for each virus suspension was performed according to the Reed and Muench method [19].

\section{Challenge in the $B A L B / C$ Mice Lineage}

The pathogenic potential of the new isolate was determined in 6-week-old female BALB/c mice purchased from Orient, South Korea $(n=10)$, that were intranasally inoculated with $10^{4} \mathrm{EID} 50 / \mathrm{mL}$ of the virus. Mice were anesthetized using $1 \%$ isoflurane following the manufacturer's instructions (Hana Pharmacy, South Korea) and the guidelines of Vertebrate Animal Research, University of Iowa [20]. The body weight and survival rate of mice were observed for 14 days. Mice were euthanized and their lungs collected at days 3,6 , and 14 postinfection $(n=3)$. The lung tissue was homogenized, and TCID50 was determined to test the viral titers of the homogenate supernatant [17].

Preparation of Mice Antisera and Hemagglutination Assay

Whole virus samples were prepared from MDCK cells or 10 -day-old ECEs and inactivated with $0.02 \%$ formalin (final con- centration) for $16 \mathrm{~h}$ at $37^{\circ} \mathrm{C}$. After pelleting by ultracentrifugation at $112,600 \mathrm{~g}$ for $2 \mathrm{~h}$ at $4^{\circ} \mathrm{C}$ and resuspension in PBS, viral protein concentration was measured according to Bradford. The inactivated viral antigen was emulsified by incomplete Freund's adjuvant and subcutaneously inoculated at $50 \mu \mathrm{g} /$ mouse ( 2 times per week). Four weeks after immunization, blood was collected to obtain the serum, and the sample tubes were centrifuged at 1,200 $\mathrm{g}$ for $10 \mathrm{~min}$ at $20-25^{\circ} \mathrm{C}$.

Serum samples were pretreated with the receptor-destroying enzyme (RDE, $1: 3 \mathrm{v} / \mathrm{v}$; Denka Seiken, Japan) at $10 \mu \mathrm{L}$ serum per 30 $\mu \mathrm{L}$ RDE at $37^{\circ} \mathrm{C}$ for $18 \mathrm{~h}$ followed by $56^{\circ} \mathrm{C}$ for $30 \mathrm{~min}$. To remove nonspecific agglutinins, $10 \mu \mathrm{L} 20 \%$ red blood cell suspension was added, resulting in a 5 -fold dilution of the serum, and then incubated at $4^{\circ} \mathrm{C}$ for $2 \mathrm{~h}$, gently rotating. Finally, the treated serum was centrifuged at $800 \mathrm{~g}$ for $10 \mathrm{~min}$ at $4^{\circ} \mathrm{C}$, and the supernatant was collected. The cross-reactivity among virus subtypes was examined using the antiserum to each subtype and the HA inhibition assay, as described by Kaufmann et al. [21]. In brief, mice antisera were treated with RDE and then serially diluted with PBS, mixed 


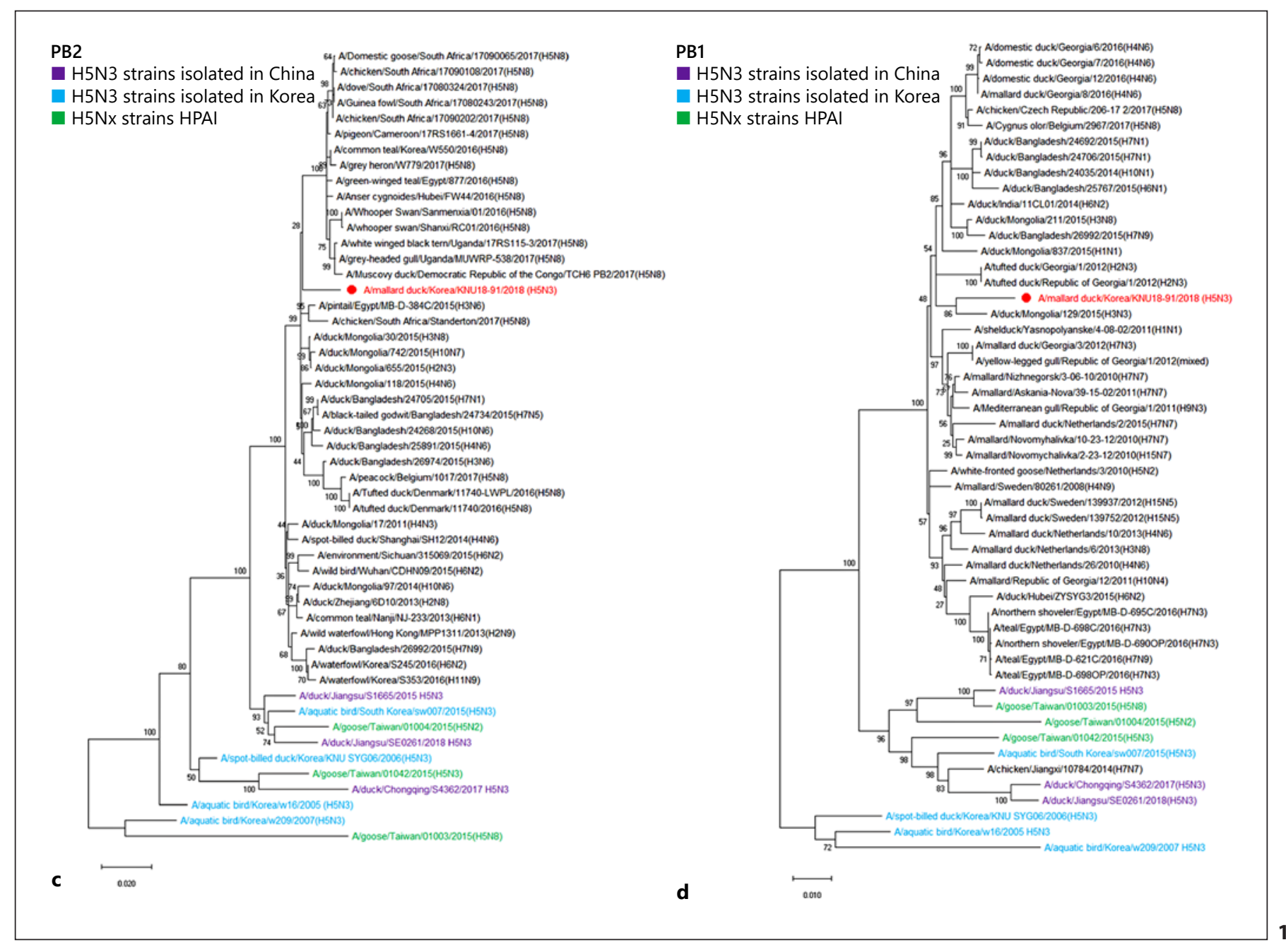

(Figure continued on next pages.)

with 4 hemagglutination units of the virus, and incubated for 30 min at $20-25^{\circ} \mathrm{C}$. HA inhibition was obtained from the highest serum sample dilution that inhibited hemagglutination.

\section{Statistical Analysis}

The mean, standard deviation (SD), and Student's $t$ test results were analyzed using GraphPad Prism software (https://www. graphpad.com/scientific-software/prism/). Results are presented as mean \pm standard deviation. A value of $p<0.05$ was considered significant.

\section{Results}

\section{Virus Isolation and Gene Sequencing}

Thirty of the 500 fecal samples collected from wild birds, including the graylag goose, big goose, mandarin duck, rump pigeon, and mallard duck/spot-billed duck in 2018, were AIV-positive according to the hemagglutina- tion assay. Among them, a virus was determined as $\mathrm{H} 5$ subtype AIV based on its specific PCR amplification. Further sequencing of the $H A$ and $N A$ genes revealed that an isolate (A/mallard duck/Korea/KNU18-91/2018 [H5N3]), collected from Hwaseong Sihwa Lake, Gyeong-

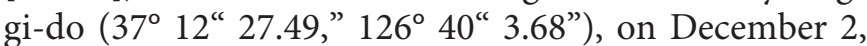
2018, was of the H5N3 subtype (Fig. 1).

The reads of KNU18-91 showed a 3.9\% reading rate (influenza virus:non-influenza virus $=735257: 18634633$ ), and all ORFs were complete (Table 1). The full genome analysis of the KNU18-91 isolate is shown in online suppl. Table 1; for all online suppl. material, see www.karger. com/doi/10.1159/000517057, and all full sequences were deposited in the NCBI GenBank database, with an accession number of 8 gene segments (PB2, PB1, PA, HA, NP, NA, MP, and NS) which are MN493049-MN493053, MN559721, MN493054, and MN559722, respectively. 


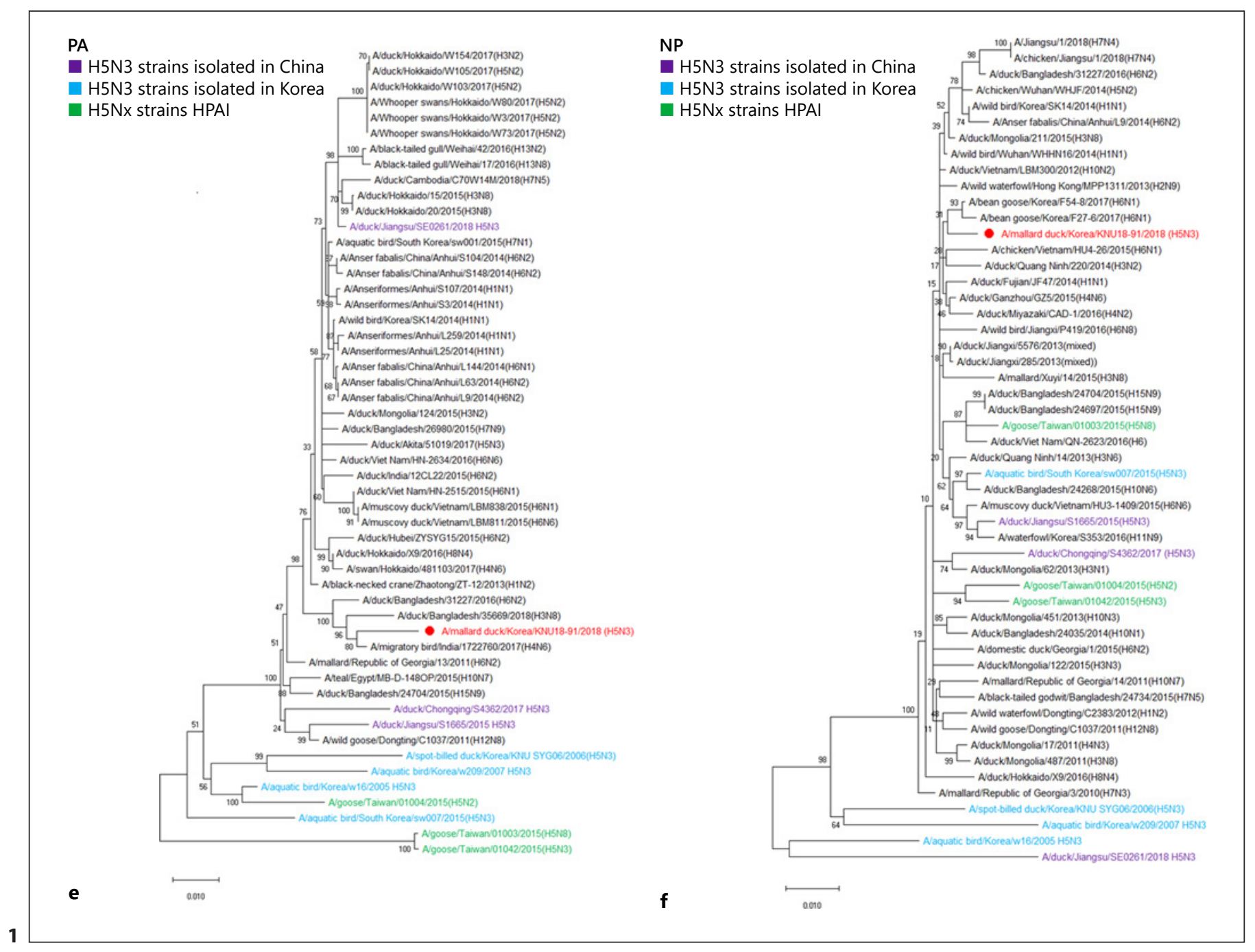

(Figure continued on next pages.)

Molecular Characterization of the KNU18-91 (H5N3) Isolate

To better define the animal and public health risk of the new H5N3 isolate, potential molecular biomarkers associated with the drug resistance, enhanced mammalian affinity, and increased virulence were reviewed. The KNU18-91 had an amino acid sequence (PQRETR/GLF) at the cleavage site between HA1 and HA2, indicating it was an LPAI strain. Amino acid residues 150A, 202E, 206L, 237G, 238Q, and 240G with preferential binding to avian-like receptors were observed in the $H A$ gene at the receptor-binding pocket region of the isolate, showing no specific recognition of human-like receptors (Table 2).

The stalk domain of the neuraminidase gene of KNU18-91 was complete, without any fragment deletion, indicating a typical LPAI virus. The 13 amino acid substi- tutions known to enhance the replication ability of $\mathrm{H} 5$ AIVs in mammals were found in the gene segments of KNU18-91: Q368R and H447Q in PB2; D/A3V, L13P, and $\mathrm{K} 328 \mathrm{~N}$ in $P B 1$; one N66S mutation in $P B 1-F 2$, which has 90 amino acids; S37A and S/A515T in $P A ; \mathrm{A} / \mathrm{I} / \mathrm{P} / \mathrm{S} /$ $\mathrm{T} 86 \mathrm{~V}, \mathrm{Q} / \mathrm{H} / \mathrm{I} 138 \mathrm{~N}$, and $\mathrm{K} 212 \mathrm{E} / \mathrm{R} / \mathrm{G}$ in $H A$; and $\mathrm{R} 143 \mathrm{~K}$ and T223I in NA. These mutations showed that the KNU18-91 (H5N3) isolate may increase its replication efficiency and its virulence in avian and mammalian hosts (Table 3).

The mutations in the KNU18-91 (H5N3) isolate were compared to those in the SBD/Korea/KNU SYG06/06 H5N3 strain. Eight mutations, differing from those of KNU18-91, were found in the gene segments of SBD/Korea/KNU SYG06/06 (H5N3): Asn (N) in PB1-F2 at position 66 , Iso (I) in $H A$ at position $86,42 \mathrm{~S}, 87 \mathrm{~S}, 98 \mathrm{M}, 101 \mathrm{D}$, 


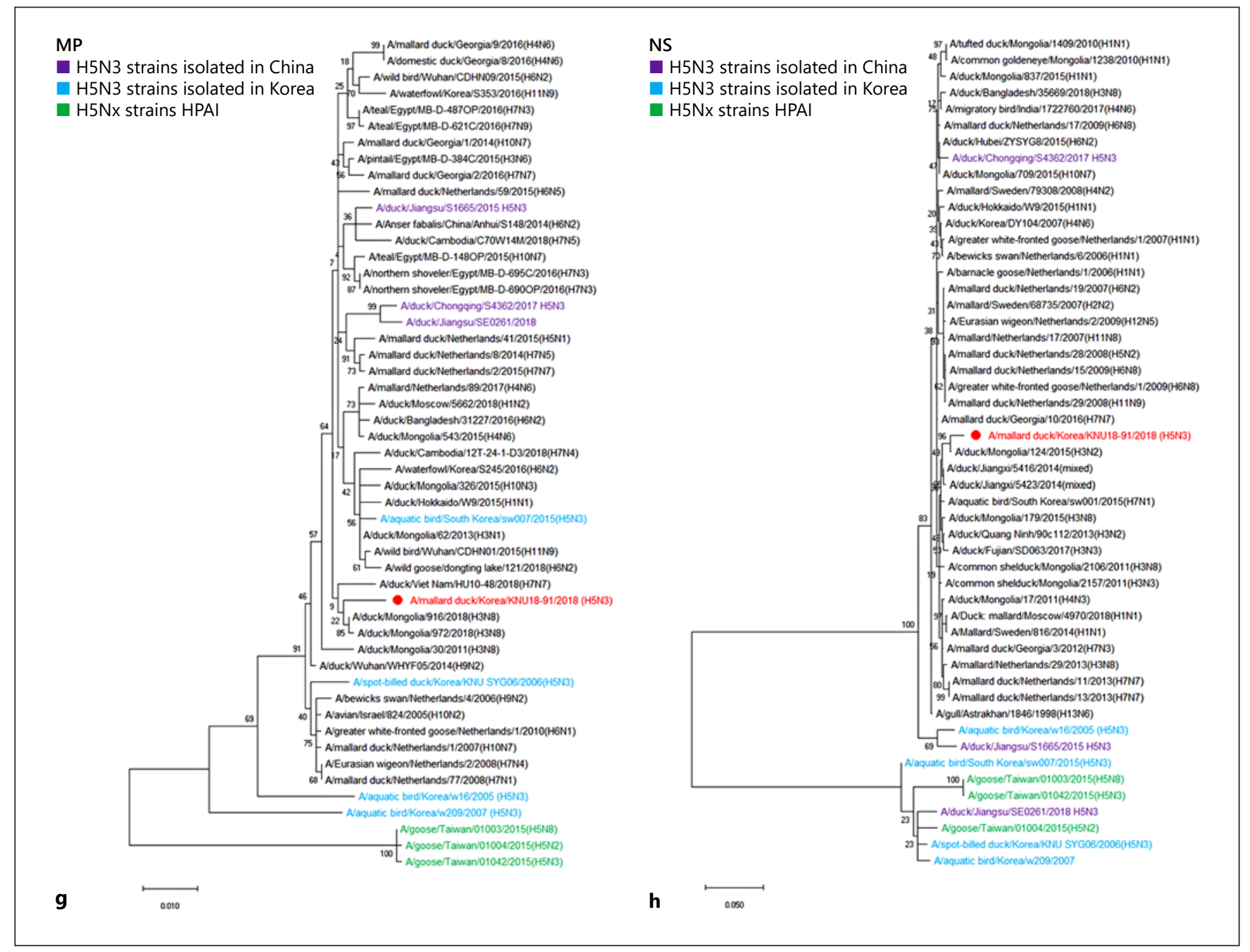

Fig. 1. Phylogenetic analysis of $\mathrm{H} 5 \mathrm{~N} 3$ viruses for 8 gene segments of KNU18-91: HA (a), NA (b), PB2 (c), PB1 (d), PA (e), NP (f), MP (g), MS (h). The trees were conducted by MEGA 6.0 software with 1000 bootstrap replication. The KNU18-91 gene segments are indicated in red color, isolated H5N3 strains in Korea are shown

$127 \mathrm{~N}$, and $228 \mathrm{~S}$ in NS1, and Val in M2 at position 72. Among these mutations, 6 (66N in PB1-F2; 42S, 87S, $98 \mathrm{M}, 101 \mathrm{D}$, and $228 \mathrm{~S}$ in NS1) were similar to both HPAI H5 AVIs, namely A/chicken/Nigeria/15VIR339-2/2015 (H5N1) and A/goose/Taiwan/01042/2015 (H5N3) (Table 3$)$.

The lately reported Korean H5N3 (A/aquatic bird/ South Korea/sw007/2015 [H5N3]) showed 14 mutations related to enhanced virulence, and KNU18-91 isolate showed 12 same mutations with A/aquatic bird/South Korea/sw007/2015 (H5N3). However, KNU18-91 in- in blue, purple color indicates $\mathrm{H} 5 \mathrm{~N} 3$ strains isolated in China, highly pathogenic of $\mathrm{H} 5$ avian influenza virus strains are shown in green color. HA, hemagglutinin; NA, neuraminidase; HPAI, highpathogenic avian influenza. cluded N66S mutation in PB1-F2 which was not seen in A/aquatic bird/South Korea/sw007/2015 (H5N3) strain, implying that KNU18-91 may be less virulent than A/ aquatic bird/South Korea/sw007/2015 (H5N3). One mutation (N66S) in PB1-F2 which has been shown to increase the pathogenesis associated with H5N1 Hong Kong/1997 and H1N1 Brevig Mission/1918 influenza viruses was distinctively observed in KNU18-91 unlikely HPAI H5 subtype or A/aquatic bird/South Korea/ sw007/2015 (H5N3) [23]. 
Table 2. Amino acid sequences of the KNU18-91 isolate at the cleavage site and RBS for the $H A$ gene [22, 23]

\begin{tabular}{|c|c|c|c|c|c|c|c|c|}
\hline \multirow[t]{2}{*}{ Strain } & \multirow{2}{*}{$\frac{\text { HA cleavage site }}{\text { amino acids 339-349 }}$} & \multicolumn{6}{|c|}{ Conserved amino acids in $\mathrm{RBS}^{\mathrm{c}}$} & \multirow[t]{2}{*}{ Reference } \\
\hline & & 150 & 202 & 206 & 237 & 238 & 240 & \\
\hline \multicolumn{9}{|l|}{ Low Pathogenicity } \\
\hline KNU18-91 & PQRETR $^{\mathrm{a}} / \mathrm{GLF}$ & $\mathrm{A}$ & $\mathrm{E}$ & $\mathrm{L}$ & G & Q & G & \multirow[t]{2}{*}{ New isolate } \\
\hline SBD/Korea/KNU SYG06/06 (H5N3) & PQRETR/GLF & $\mathrm{A}$ & $\mathrm{E}$ & $\mathrm{L}$ & G & Q & G & \\
\hline A/aquatic bird/South Korea/sw007/2015(H5N3) & PQRETR/GLF & A & $\mathrm{E}$ & $\mathrm{L}$ & G & Q & G & \\
\hline Mallard/JiangXi/13487/05 (H5N3) & PQRETR/GLF & A & $\mathrm{E}$ & $\mathrm{L}$ & G & Q & G & [22] \\
\hline A/duck/Jiangsu/S1665/2015 H5N3 & PQRETR/GLF & $\mathrm{A}$ & $\mathrm{E}$ & $\mathrm{L}$ & G & Q & $\mathrm{A}$ & \multirow{5}{*}[9]{} \\
\hline A/wild bird/Eastern China/1754/2017 H5N3 & PQRETR/GLF & A & $\mathrm{E}$ & $\mathrm{L}$ & G & Q & G & \\
\hline A/wild bird/Eastern China/1758/2017 H5N3 & PQRETR/GLF & $\mathrm{A}$ & $\mathrm{E}$ & $\mathrm{L}$ & G & $\mathrm{Q}$ & G & \\
\hline A/wild bird/Eastern China/1759/2017 H5N3 & PQRETR/GLF & A & $\mathrm{E}$ & $\mathrm{L}$ & G & Q & G & \\
\hline A/duck/Chongqing/S4362/2017 H5N3 & PQRETR/GLF & $\mathrm{A}$ & $\mathrm{E}$ & $\mathrm{L}$ & G & $\mathrm{Q}$ & G & \\
\hline A/goose/Taiwan/01042/2015(H5N3) & RERRRKR $\mathbf{b} / G L F$ & A & $\mathrm{E}$ & $\mathrm{L}$ & G & Q & G & \multirow{3}{*}[23]{} \\
\hline A/goose/Taiwan/01004/2015(H5N2) & RERRRKR/GLF & $\mathrm{A}$ & $\mathrm{E}$ & $\mathrm{L}$ & G & $\mathrm{Q}$ & G & \\
\hline A/goose/Taiwan/01003/2015(H5N8) & RERRRKR/GLF & A & $\mathrm{E}$ & $\mathrm{L}$ & G & Q & G & \\
\hline
\end{tabular}

RBS, receptor-binding site; HA, hemagglutinin. ${ }^{a}$ Monobasic cleavage site. ${ }^{b}$ Polybasic cleavage site. ${ }^{c}$ Receptor binding site.

\section{Phylogenetic Analysis and Genesis of H5N3 Strains}

In the phylogenetic trees constructed for the 8 viral gene segments, the KNU18-91 isolate appeared most closely related to Eurasian lineages (Fig. 1a-h). The phylogenetic tree for the HA segment of KNU18-91 revealed it was mainly clustered with influenza viruses circulating in China from 2017 to 2018, whereas NA was clustered with Eurasian lineages, with a close relationship to Mongolian (A/duck/Mongolia/129/2015 and A/duck/Mongolia/518/2015) and Vietnamese (A/duck/Vietnam/HN26-33/2016) isolates.

Phylogenetic trees of $P B 2, P B 1, P A, N P, M$, and NS internal genes revealed these were clustered in a group circulating in Mongolia from 2015 to 2018. The highest homolog similarity analysis based on the nucleotide sequences from GISAID database (https://platform.gisaid. org/epi3) of 8 gene segments was also carried out in which the $P B 2$ segment is $99 \%$ homologous to the Mongolia strain (2015); PB1 and NA segments show 98-99\% similarity with Bangladesh strains, respectively; the PA gene shows $98 \%$ with H1N1 strain from Belgium; HA and NS gene segments represent highest homology with viruses from Japan reported in 2015-2016 (98-99\%, respectively); NP and M genes are similar to viruses reported in 2017 from Korea and the Netherlands (Table 4).
The amino acid homology of KNU18-91 with previously reported Korean isolates was the following: $P B 2$, 98.55-99.57\%; PB1, 98.28-99.34\%; $P A, 98.88-99.16 \%$; $H A$, 96.99-99.29\%; NP, 96.77-99.8\%; NA, 94.46-97.44\%; M, 99.04-100\%; and NS, 61.22-89.29\% (Table 5). Based on the phylogenetic and homolog distribution analyses, a complex evolutionary history of KNU18-91 with multiple reassortments was inferred (Fig. 2). It indicated that KNU18-91 could be a complex reassortment that took place around 2015-2018 in Mongolia, where the HA and $N A$ genes originated from duck $\mathrm{H} 5$ viruses from China and duck N3 viruses from Mongolia, respectively. An unidentified precursor virus may have been generated with $M, P B 2, P B 1, N A, P A, N P$, and NS segments in Mongolia in 2015-2018, and $H A$ segments of A/duck/Jiangsu/ S1665/2015 (H5N3) were donated to this unknown virus. The donating virus may have disseminated to South Korea in 2017-2018. The $P B 1$ and NA segments originated from a Mongolian duck (H3N3) in 2015 with an ancestor virus from Georgia (A/tufted duck/Georgia/1/2012 [H2N3]), and PA and NS segments originated from a Mongolia duck 2015 (H3N2). Other internal segments (PB2, NP, and $M$ ) were contributed by H3N8 (20152018) from Mongolia. 
Table 3. Amino acid substitutions responsible for increased polymerase activity, viral transmissibility, and virulence of AIVs [24-70]

\begin{tabular}{|c|c|c|c|c|c|c|c|c|}
\hline Function & $\begin{array}{l}\text { Influenza virus } \\
\text { gene segment }\end{array}$ & & $\mathrm{H} 5 \mathrm{N1}^{\mathrm{a}}$ & $\mathrm{H} 5 \mathrm{~N} 3^{\mathrm{b}}$ & $\mathrm{H} 5 \mathrm{~N}^{\mathrm{c}}{ }^{\mathrm{c}}$ & $\mathrm{H} 5 \mathrm{~N} 3^{\mathrm{d}}$ & KNU18-91 & Reference \\
\hline \multirow{58}{*}{$\begin{array}{l}\text { Enhanced replication } \\
\text { efficiency / virulence }\end{array}$} & \multirow[t]{14}{*}{ PB2 } & Ms28I & M & M & M & M & M & {$[24,25]$} \\
\hline & & $\mathrm{A} 274 \mathrm{~T}$ & A & A & A & A & A & {$[24]$} \\
\hline & & $\mathrm{R} 318 \mathrm{~K}$ & $\mathrm{R}$ & $\mathrm{R}$ & $\mathrm{R}$ & $\mathrm{R}$ & $\mathrm{R}$ & {$[26,27]$} \\
\hline & & R/Q355K & $\mathrm{R}$ & $\mathrm{R}$ & $\mathrm{R}$ & $\mathrm{R}$ & $\mathrm{R}$ & {$[26,28,29]$} \\
\hline & & Q368R & $\mathrm{R}$ & $\mathrm{R}$ & $\mathrm{R}^{1}$ & $\mathrm{R}$ & $\mathrm{R}^{2}$ & {$[24,30,31]$} \\
\hline & & E391Q & $\mathrm{E}$ & $\mathrm{E}$ & $\mathrm{E}$ & $\mathrm{E}$ & $\mathrm{E}$ & \\
\hline & & H447Q & $\mathrm{Q}$ & $\mathrm{Q}$ & $\mathrm{Q}^{1}$ & Q & $\mathrm{Q}^{2}$ & \\
\hline & & K526R & $\mathrm{K}$ & $\mathrm{K}$ & $\mathrm{K}$ & $\mathrm{K}$ & $\mathrm{K}$ & {$[24]$} \\
\hline & & M535L & M & M & M & $\mathrm{M}$ & M & {$[32]$} \\
\hline & & $\mathrm{I} 553 \mathrm{~V}$ & I & I & I & I & I & {$[24]$} \\
\hline & & Q591K & Q & Q & Q & Q & $\mathrm{Q}$ & {$[33]$} \\
\hline & & E627K & $\mathrm{E}$ & $\mathrm{E}$ & $\mathrm{E}$ & $\mathrm{E}$ & $\mathrm{E}$ & [34] \\
\hline & & D701N & $\mathrm{D}$ & $\mathrm{D}$ & $\mathrm{D}$ & $\mathrm{D}$ & $\mathrm{D}$ & [35] \\
\hline & & S714R & $S$ & S & $S$ & $S$ & $S$ & [36] \\
\hline & \multirow[t]{5}{*}{ PB1 } & $\mathrm{D} / \mathrm{A} 3 \mathrm{~V}$ & V & V & $\mathrm{V}^{1}$ & V & $\mathrm{V}^{2}$ & {$[30,31]$} \\
\hline & & L13P & $\mathrm{P}$ & $\mathrm{P}$ & $\mathrm{P}^{1}$ & $\mathrm{P}$ & $\mathrm{P}^{2}$ & [36] \\
\hline & & $\mathrm{M} / \mathrm{V} 317 \mathrm{I}$ & $\mathrm{V}$ & $\mathrm{M}$ & M & M & M & {$[28,29]$} \\
\hline & & $\mathrm{K} 328 \mathrm{~N}$ & $\mathrm{~N}$ & $\mathrm{~N}$ & $\mathrm{~N}^{1}$ & $\mathrm{~N}$ & $\mathrm{~N}^{2}$ & {$[30,31]$} \\
\hline & & S678N & S & $S$ & $S$ & $S$ & $\mathrm{~S}$ & {$[36]$} \\
\hline & \multirow{2}{*}{ PB1-F2 } & N66S & $\mathrm{N}$ & $\mathrm{N}$ & $\mathrm{N}$ & $\mathrm{N}^{*}$ & $\mathrm{~S}^{2}$ & [23] \\
\hline & & 87-90 amino acids in length & 90 & 90 & 90 & 90 & 90 & {$[37]$} \\
\hline & \multirow[t]{9}{*}{ PA } & S37A & A & A & $\mathrm{A}^{1}$ & A & $\mathrm{A}^{2}$ & {$[38]$} \\
\hline & & V127I/A & $\mathrm{V}$ & $\mathrm{V}$ & $\mathrm{V}$ & $\mathrm{V}$ & $\mathrm{V}$ & {$[27]$} \\
\hline & & S149P & S & S & S & $S$ & S & {$[24]$} \\
\hline & & L336M & $\mathrm{L}$ & $\mathrm{L}$ & $\mathrm{L}$ & $\mathrm{L}$ & $\mathrm{L}$ & {$[27]$} \\
\hline & & A343T & S & A & A & A & A & [39] \\
\hline & & K356R & K & K & K & K & K & {$[40]$} \\
\hline & & $\mathrm{I} 357 \mathrm{~K}$ & $\mathrm{~T}$ & $\mathrm{~T}$ & $\mathrm{~T}$ & $\mathrm{~T}$ & $\mathrm{~T}$ & {$[24]$} \\
\hline & & S/A515T & $\mathrm{T}$ & $\mathrm{T}$ & $\mathrm{T}^{1}$ & $\mathrm{~T}$ & $\mathrm{~T}^{2}$ & \\
\hline & & K615N & K & K & K & K & K & {$[36]$} \\
\hline & \multirow[t]{7}{*}{ HA } & $\mathrm{A} / \mathrm{I} / \mathrm{P} / \mathrm{S} / \mathrm{T} 86 \mathrm{~V}$ & A & & $\mathrm{V}^{1}$ & $\mathrm{I}^{*}$ & $\mathrm{~V}^{2}$ & {$[27]$} \\
\hline & & N/D124S & $\mathrm{D}$ & & $\mathrm{N}$ & $\mathrm{N}$ & $\mathrm{N}$ & \\
\hline & & $\mathrm{Q} / \mathrm{H} / \mathrm{I} 138 \mathrm{~L} / \mathrm{N}$ & Q & & $\mathrm{N}^{1}$ & $\mathrm{~N}$ & $\mathrm{~N}^{2}$ & \\
\hline & & $\mathrm{N} / \mathrm{K} 189 \mathrm{~S} / \mathrm{R} / \mathrm{D} / \mathrm{E}$ & $\mathrm{K}$ & & $\mathrm{K}$ & $\mathrm{K}$ & $\mathrm{K}$ & [41] \\
\hline & & $\mathrm{K} 212 \mathrm{E} / \mathrm{R} / \mathrm{G}$ & K & & $E^{1}$ & $\mathrm{E}$ & $\mathrm{E}^{2}$ & {$[27]$} \\
\hline & & A263T & $\mathrm{T}$ & & A & A & A & \\
\hline & & N376 T & G & & G & G & G & {$[42]$} \\
\hline & NP & K470R & K & K & K & K & K & {$[43]$} \\
\hline & \multirow[t]{6}{*}{ NA } & 49-68 deletion & Deletion $49-62$ & No deletion & No deletion & No deletion & No deletion & {$[44]$} \\
\hline & & $\mathrm{E} 119 \mathrm{~K} / \mathrm{D}$ & $\mathrm{R}$ & $\mathrm{R}$ & $\mathrm{R}$ & $\mathrm{R}$ & $\mathrm{R}$ & {$[45]$} \\
\hline & & $\mathrm{R} 143 \mathrm{~K}$ & K & K & $\mathrm{K}^{1}$ & K & $\mathrm{K}^{2}$ & {$[46]$} \\
\hline & & G147E & G & G & G & G & G & \\
\hline & & T223I & I & I & $\mathrm{I}^{1}$ & I & $\mathrm{I}^{2}$ & {$[28,29]$} \\
\hline & & $\mathrm{H} 275 \mathrm{Y}$ & $\mathrm{Y}$ & Q & Q & Q & Q & {$[47]$} \\
\hline & \multirow[t]{14}{*}{ NS1 } & M31I & $\mathrm{P}$ & $\mathrm{P}$ & $\mathrm{P}$ & $\mathrm{P}$ & $\mathrm{P}$ & {$[48]$} \\
\hline & & $\mathrm{A} / \mathrm{P} 42 \mathrm{~S}$ & S & $\mathrm{S}$ & $\mathrm{S}^{1}$ & $\mathrm{~S}^{*}$ & A & {$[27]$} \\
\hline & & G45R & G & G & G & G & G & {$[49]$} \\
\hline & & $\mathrm{D} 74 \mathrm{~N}$ & $\mathrm{D}$ & $\mathrm{D}$ & $\mathrm{D}$ & $\mathrm{D}$ & $\mathrm{D}$ & {$[50]$} \\
\hline & & Amino acids $80-4$ deletion2 & Deletion & No deletion & No deletion & No deletion & No deletion & {$[51]$} \\
\hline & & D87E & S & S & S & $\mathrm{S}^{*}$ & $\mathrm{P}$ & {$[52]$} \\
\hline & & T/D92E & $\mathrm{E}$ & $\mathrm{D}$ & $\mathrm{D}$ & $\mathrm{D}$ & $\mathrm{D}$ & {$[27,29]$} \\
\hline & & L98F & $\mathrm{M}$ & $\mathrm{M}$ & $\mathrm{M}$ & $\mathrm{M}^{*}$ & I & [53] \\
\hline & & $\mathrm{I} 101 \mathrm{M}$ & $\mathrm{D}$ & $\mathrm{D}$ & $\mathrm{D}$ & $D^{*}$ & $\mathrm{E}$ & \\
\hline & & $\mathrm{T} / \mathrm{D} / \mathrm{V} / \mathrm{R} / \mathrm{A} 127 \mathrm{~N}$ & $\mathrm{~T}$ & $\mathrm{~T}$ & $\mathrm{~N}^{1}$ & $\mathrm{~N}^{*}$ & $\mathrm{R}$ & {$[27]$} \\
\hline & & $\mathrm{D} / \mathrm{G} 189 \mathrm{~N}$ & $\mathrm{D}$ & $\mathrm{D}$ & $\mathrm{D}$ & $\mathrm{D}$ & $\mathrm{D}$ & \\
\hline & & S195T/Y & S & S & $\mathrm{S}$ & S & $\mathrm{S}$ & {$[27,48]$} \\
\hline & & S228P & $\mathrm{S}$ & $\mathrm{S}$ & S & $\mathrm{S}^{*}$ & Q & {$[27]$} \\
\hline & & PDZ domain (X-S/T-X-V at positions 222-225) & LARA & MART & MART & MART & WRDE & {$[54]$} \\
\hline \multirow{6}{*}{$\begin{array}{l}\text { Enhanced binding to } \\
\alpha 2,6\end{array}$} & \multirow[t]{6}{*}{ HA } & N182K (186 in H3) & $\mathrm{N}$ & & $\mathrm{N}$ & $\mathrm{N}$ & $\mathrm{N}$ & [55] \\
\hline & & V210I (214 in H3) & $\mathrm{V}$ & & $\mathrm{V}$ & $\mathrm{V}$ & $\mathrm{V}$ & {$[56]$} \\
\hline & & Q222L (226 in H3) & Q & & Q & Q & Q & {$[57]$} \\
\hline & & S223N (227 in H3) & $\mathrm{S}$ & & $\mathrm{S}$ & $\mathrm{s}$ & $\mathrm{S}$ & {$[58]$} \\
\hline & & G224S (228 in H3) & G & & G & G & G & {$[57]$} \\
\hline & & $\begin{array}{l}\text { N154D, N220K, Q222L, T315I }(158,224,226,318 \\
\text { in H3) }\end{array}$ & $\mathrm{X}, \mathrm{N}, \mathrm{Q}, \mathrm{T}$ & & $\mathrm{N}, \mathrm{N}, \mathrm{Q}, \mathrm{T}$ & $\mathrm{N}, \mathrm{N}, \mathrm{Q}, \mathrm{T}$ & $\mathrm{N}, \mathrm{N}, \mathrm{Q}, \mathrm{T}$ & [59] \\
\hline
\end{tabular}


Table 3 (continued)

\begin{tabular}{|c|c|c|c|c|c|c|c|c|}
\hline Function & $\begin{array}{l}\text { Influenza virus } \\
\text { gene segment }\end{array}$ & & $\mathrm{H} 5 \mathrm{~N}^{\mathrm{a}}$ & $\mathrm{H} 5 \mathrm{~N} 3^{\mathrm{b}}$ & $\mathrm{H} 5 \mathrm{~N}^{\mathrm{c}}$ & $\mathrm{H} 5 \mathrm{~N}^{\mathrm{d}}$ & KNU18-91 & Reference \\
\hline \multirow{12}{*}{$\begin{array}{l}\text { Reduced susceptibility } \\
\text { to NA inhibitors }\end{array}$} & \multirow[t]{12}{*}{ NA } & V96A (116 in N2) & V & $\mathrm{V}$ & $\mathrm{V}$ & $\mathrm{V}$ & $\mathrm{V}$ & {$[60]$} \\
\hline & & I97V (117 in N2) & I & $\mathrm{T}$ & $\mathrm{T}$ & $\mathrm{T}$ & $\mathrm{T}$ & {$[61]$} \\
\hline & & $\mathrm{E} 99 \mathrm{~A} / \mathrm{G}(119$ in N2) & $\mathrm{E}$ & $\mathrm{E}$ & $\mathrm{E}$ & $\mathrm{E}$ & $\mathrm{E}$ & {$[62]$} \\
\hline & & Q116L (136 in N2) & Q & Q & Q & Q & Q & {$[63]$} \\
\hline & & V129A (149 in N2) & $\mathrm{V}$ & I & I & I & I & {$[64]$} \\
\hline & & D179G (198 in N2) & $\mathrm{P}$ & $\mathrm{N}$ & $\mathrm{N}$ & $\mathrm{N}$ & $\mathrm{N}$ & {$[65]$} \\
\hline & & I203M (222 in N2) & $\mathrm{N}$ & $\mathrm{D}$ & $\mathrm{D}$ & $\mathrm{D}$ & $\mathrm{D}$ & \\
\hline & & S227N (246 in N2) & $\mathrm{P}$ & $\mathrm{P}$ & $\mathrm{P}$ & $\mathrm{P}$ & $\mathrm{P}$ & {$[60]$} \\
\hline & & H255Y (274 in N2) & $\mathrm{Y}$ & I & I & I & I & [62] \\
\hline & & N275S (294 in N2) & $\mathrm{N}$ & $\mathrm{N}$ & $\mathrm{N}$ & $\mathrm{N}$ & $\mathrm{N}$ & \\
\hline & & $\mathrm{I} 97 \mathrm{~V}+\mathrm{I} 294 \mathrm{~V}(117+314$ in $\mathrm{N} 2)$ & I, I & $\mathrm{T}, \mathrm{T}$ & $\mathrm{T}, \mathrm{T}$ & $\mathrm{T}, \mathrm{T}$ & $\mathrm{T}, \mathrm{T}$ & {$[66]$} \\
\hline & & $\mathrm{K} 130 \mathrm{~N}+\mathrm{I} 203 \mathrm{~L}+\mathrm{S} 227 \mathrm{~N}(150+222+246$ in N2) & $\mathrm{K}, \mathrm{N}, \mathrm{P}$ & $\mathrm{K}, \mathrm{N}, \mathrm{P}$ & $\mathrm{K}, \mathrm{N}, \mathrm{P}$ & $\mathrm{K}, \mathrm{N}, \mathrm{P}$ & $\mathrm{K}, \mathrm{N}, \mathrm{P}$ & {$[60]$} \\
\hline \multirow{3}{*}{$\begin{array}{l}\text { Reduced susceptibility } \\
\text { to adamantanes }\end{array}$} & \multirow[t]{3}{*}{ M2 } & V27A & I & $\mathrm{V}$ & $\mathrm{V}$ & $\mathrm{V}$ & $\mathrm{V}$ & {$[67]$} \\
\hline & & A30S & A & A & A & A & A & {$[68,69]$} \\
\hline & & S31N & S & $\mathrm{N}$ & S & S & S & {$[70]$} \\
\hline
\end{tabular}

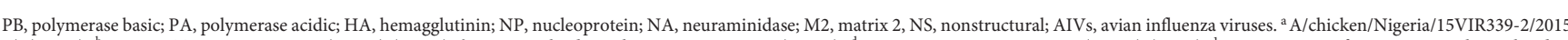
(H5N1) (HPAI). ${ }^{b} \mathrm{~A} /$ goose/Taiwan/01042/2015(H5N3) (HPAI). ${ }^{\mathrm{c}} \mathrm{A} /$ aquatic bird/South Korea/sw007/2015(H5N3). ${ }^{\mathrm{d}}$ SBD/Korea/KNU SYG06/06 (H5N3) (LPAI). ${ }^{1}$ Mutation site of KNU18-91 isolate related to enhanced adaptation in mammals. ${ }^{2}$ Mutation site of A/aquatic bird/South Korea/sw007/2015(related to enhanced adaptation in mammals. * Different mutation between KNU18-91 and SBD/Korea/KNU SYG06/06 ( $\mathrm{H} 5 \mathrm{~N} 3)$.

Table 4. Nearest nucleotide homologs of the 8 gene segments of the KNU18-91 isolate retrieved from the GISAID database

\begin{tabular}{|c|c|c|c|c|}
\hline \multirow[t]{2}{*}{ Gene } & \multirow[t]{2}{*}{ Virus with the highest nucleotide $\%$ identity } & \multirow{2}{*}{$\begin{array}{l}\text { Accession } \\
\text { number }\end{array}$} & \multicolumn{2}{|l|}{ \% Identity } \\
\hline & & & nucleotide & amino acid \\
\hline PB2 & A/duck/Mongolia/30/2015(H3N8) & EPI704256 & 98 & 99 \\
\hline PB1 & A/duck/Bangladesh/19D691/2016 (A/H11N2) & EPI1330256 & 98 & 99 \\
\hline PA & A/Anas platyrhynchos/Belgium/11025_44/2017 (A/H11N1) & EPI1774317 & 98 & 99 \\
\hline HA & A/duck/Tokushima/361002/2015 & EPI855925 & 98 & 99 \\
\hline $\mathrm{NP}$ & $\mathrm{A} / \mathrm{mallard} /$ Korea/H906-3/2017 & EPI1226692 & 99 & 99 \\
\hline NA & A/duck/Bangladesh/18D775/2017 (A/H2N3) & EPI1330225 & 99 & 98 \\
\hline M & A/mallard/Netherlands/89/2017 (A/H4N6) & EPI1537090 & 99 & 100 \\
\hline NS & A/duck/Aichi/231013/2016 (A/H3N8) & EPI866868 & 99 & 99 \\
\hline
\end{tabular}

PB, polymerase basic; PA, polymerase acidic; HA, hemagglutinin; NP, nucleoprotein; NA, neuraminidase; M2, matrix 2, NS, nonstructural; AIVs, avian influenza viruses.

Table 5. Amino acid sequence homology of KNU18-91 and other H5N3 isolates from South Korea (A/aquatic bird/Korea/w16/2005, A/ spot-billed duck/Korea/KNU SYG06/2006, A/aquatic bird/Korea/w209/2007, and A/aquatic bird/South Korea/sw007/2015) retrieved from the NCBI database

\begin{tabular}{|c|c|c|c|c|c|c|c|c|}
\hline Strain & PB2 & PB1 & $P A$ & $H A$ & $N P$ & $N A$ & $M$ & NS \\
\hline A/spot-billed duck/Korea/KNU SYG06/2006 & 99.57 & 98.68 & 99.16 & 97.16 & 99.2 & 94.67 & 99.69 & 61.22 \\
\hline A/aquatic bird/Korea/w16/2005 & 99.42 & 98.94 & 98.88 & 97.34 & 99.8 & 96.59 & 99.37 & 89.29 \\
\hline A/aquatic bird/Korea/w209/2007 & 98.55 & 98.28 & 99.16 & 96.99 & 96.77 & 94.46 & 99.04 & 61.22 \\
\hline A/aquatic bird/South Korea/sw007/2015 & 99.08 & 99.34 & 99.02 & 99.29 & 99.39 & 97.44 & 100 & 61.60 \\
\hline
\end{tabular}

PB, polymerase basic; PA, polymerase acidic; HA, hemagglutinin; NP, nucleoprotein; NA, neuraminidase; M2, matrix 2, NS, nonstructural; AIVs, avian influenza viruses; NCBI, national center for biotechnology information. 

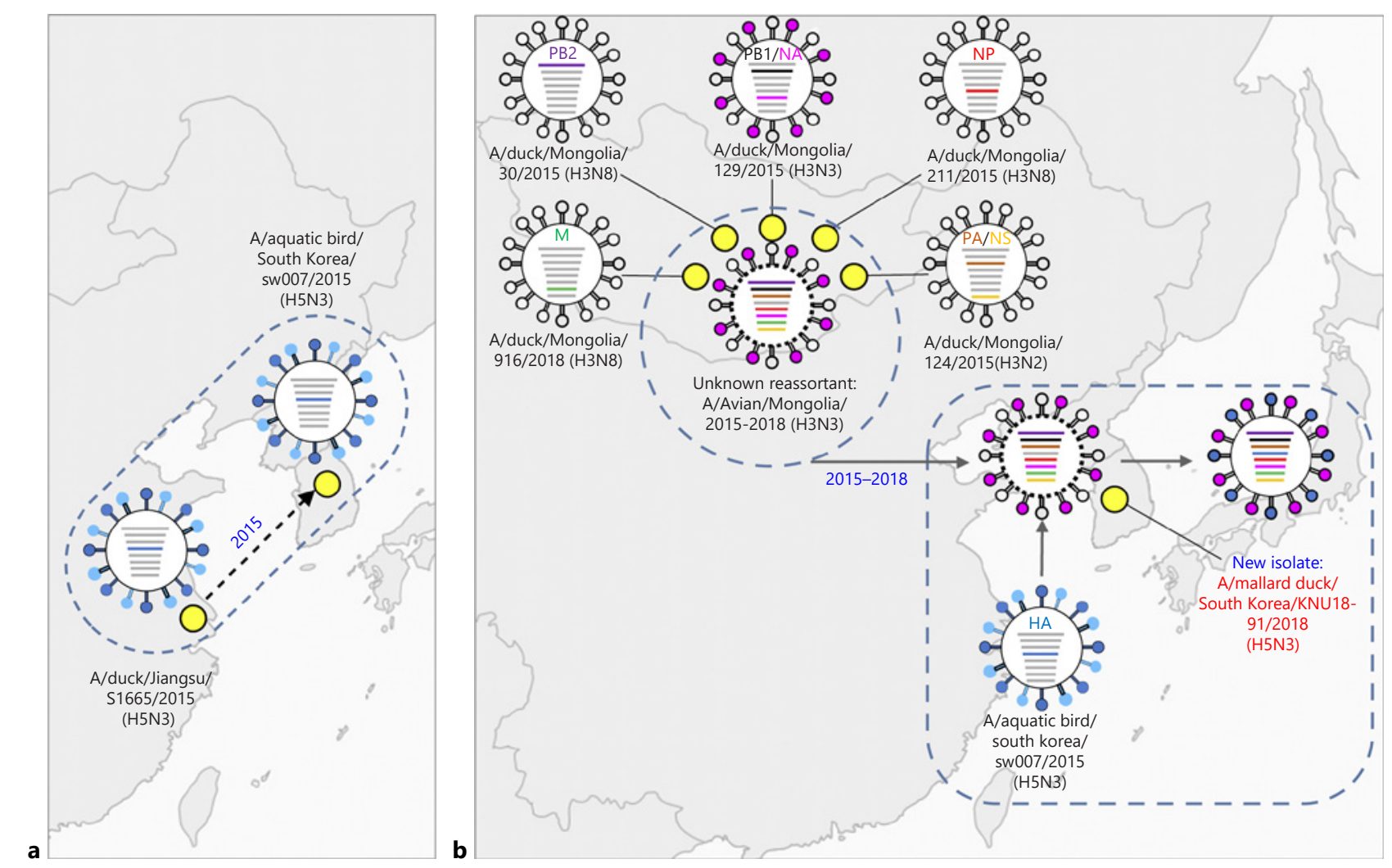

Fig. 2. Evolution hypothesis of the ancestor of each gene segment for A/mallard duck/South Korea/KNU18-91/2018 (H5N3). A/ aquatic bird/South Korea/sw007/2015 (a) and A/mallard duck/ South Korea/KNU18-91/2018 (H5N3) (b). The reassortment event is illustrated by corresponding color segments in the descendent virus. Dashed circled represents unknown strains. Dashed

According to phylogenetic tree, the all gene segments (PB2, PB1, PA, HA, NP, NA, MP, and NS) of A/ aquatic bird/South Korea/sw007/2015 (H5N3) strain were originated from A/duck/JS/S1665/2015 (H5N3) (Fig. 2a). In contrast, genesis of KNU18-91 was considered as one of the scenarios that unknown ressortant in Mongolia during 2015-2018 may contribute to novel reassortant in Korea by obtaining HA gene of pre-existing A/aquatic bird/South Korea/sw007/2015 (H5N3) (Fig. 2b). Table 5. depicts the amino acid sequence homology of KNU18-91 and other H5N3 isolates from South Korea.

Kinetics of the KNU18-91 Isolate in Mammalian Cells The KNU18-91 isolate may increase its replication efficiency and virulence in both avian and mammalian squared indicates the hypothesis in which an unknown strain in China moved to South Korea and reassorted with unknown strains originated from Mongolia, generating the KNU18-91 (H5N3) strain in South Korea. HPAI, high-pathogenic avian influenza; PB, polymerase basic.

hosts (Table 3). The growth kinetics of the KNU18-91 isolate in mammals was investigated in MDCK cells; A/ California/04/2009 (H1N1) virus, which was donated from Korea National Institute of Health (Chungju, South Korea), was used as a control in this study. Initial virus suspensions (multiplicity of infection $=0.01$ ) were inoculated to MDCK cells, and the virus supernatants were collected at $12 \mathrm{hpi}$ intervals for $72 \mathrm{~h}$; the virus titer was determined by TCID50 assay using enzyme-linked immunosorbent assay [17]. The highest virus titer $\log 10$ TCID50/mL was obtained at 36 hpi for all 3 virus strains (Fig. 3), in agreement to that previously reported for the A/California/04/2009 (H1N1) strain. The KNU18-91 $(\mathrm{H} 5 \mathrm{~N} 3)$ isolate showed higher replication in mammalian cells than the A/California/04/2009 (H1N1) virus (8.09 \pm 0.19 and $7.67 \pm 0.19 \log 10$ TCID50/mL, respectively) but 
Table 6. HA inhibition assay with mice antisera

\begin{tabular}{|c|c|c|c|c|}
\hline \multirow[t]{2}{*}{ Virus } & \multirow{2}{*}{$\begin{array}{l}\text { Accession } \\
\text { number }\end{array}$} & \multirow[t]{2}{*}{ Clade } & \multicolumn{2}{|c|}{ HA inhibition titer (dilution factor) with antiserum to } \\
\hline & & & KNU18-91 & SYG06/2006 (H5N3) EA-nonGsGD \\
\hline KNU18-91 & MN493052 & & $320^{*}$ & 20 \\
\hline SYG06/2006(H5N3) & JF800144 & EA-nonGsGD & 40 & $320^{*}$ \\
\hline
\end{tabular}

HA, hemagglutinin. * Homologous titers.

lower than the A/spot-billed duck/Korea/KNU SYG06/2006 (H5N3) virus $(8.67 \pm 0.19 \log 10$ TCID50/ $\mathrm{mL})$. Raw TCID50 results are shown in online suppl. Figure 1.

\section{Hemagglutination Inhibition Assay}

The antigenicity of KNU18-91 was characterized using the cross-hemagglutination inhibition test (Table 6). The 1:320 dilution of the antisera generated by the KNU18-91 virus was the titer to show HI with the KNU1891 virus, but these sera showed 1:40 dilution to inhibit the hemagglutination of $\mathrm{A} /$ spot-billed duck/Korea/KNU SYG06/2006(H5N3), which was one of the old Korean H5N3 strains. As there was a 16-fold difference between the 2 strains, both strains were antigenically distinct from each other as well as from KNU18-91. Raw data are shown in online suppl. Figure 3.

\section{Pathogeneticity in Female BALB/C Mice}

The pathogenic potential of KNU18-91 was evaluated in 6-week-old female BALB/c mice. Mice were intranasally infected with $10^{4}$ of EID $50 / \mathrm{mL}$ of each virus $(n=10)$. The experiment was conducted using KNU18$91, \mathrm{H} 1 \mathrm{~N} 1$, and $\mathrm{H} 5 \mathrm{~N} 3$. The mice weight and survival rate were continuously observed for 14 days postinfection (dpi). KNU18-91 has no significant effect on the survival rate (Fig. 4a), and no severe clinical signs and weight loss were observed for infections with KNU1891, H1N1, and H5N3 (Fig. 4b). As showed in Figure 4c, the KNU18-91 isolate and H5N3 weakly responded in mice lungs at $3 \mathrm{dpi}$, and their titers were $2.1 \pm 0.13$ and $2.67 \pm 0.07 \log 10$ TCID50/mL, respectively. Although there was no replication at 6 and $14 \mathrm{dpi}$ for these 2 strains, H1N1 showed a higher titer in the lung at $6 \mathrm{dpi}$ $(4.63 \log 10 \mathrm{TCID} 50 / \mathrm{mL})$. Raw data are shown in online suppl. Figure 2.

\section{Discussion}

Antigenic drift occurs during AIV circulation in poultry, and the generated antigenically variable strains can escape vaccination-induced immunity to cause avian influenza in poultry and increase the difficulty of its control $[9,71]$. The movement of HPAIVs (H5N8) across Eurasia and into North America combined with the viral propensity to reassort with co-circulating LPAIVs raises concerns among poultry producers, wildlife biologists, aviculturists, and public health personnel worldwide.

First discovered in early 2014 in poultry and wild birds in South Korea, the HPAI H5N8 virus apparently arose in China from reassortment events between the HPAI subtype H5N1 virus (clade 2.3.4.4) and several LPAIVs $[72,73]$. To track the circulation and evolution of $\mathrm{H} 5 \mathrm{Nx}$ viruses and to monitor the emergence of new reassortments from aquatic birds that induce HPAI, an annual wild nature habitat surveillance is highly demanded in different regions of South Korea. In one of these surveillances, KNU18-91 was isolated from the west coast of South Korea.

Phylogenetic and molecular analyses showed KNU1891 viruses had distinct genotypes and were closely related to LPAIVs isolated from Asia and Europe. Molecular characterization identified the pathogenic potential of the KNU18-91 isolate and showed that it had a PQRETR/ GLF sequence at the HA cleavage site, suggesting low pathogenicity [8]. Similar to that reported by Lee et al.[22] (2013) for H5N3 isolates in South Korea, the fragment deletion in the NA gene stalk region that represents wild bird virus adaptation to a new host was absent in the isolate under study, supporting LPAI of the new isolates [22, 74]. The $274 \mathrm{H}$ and $292 \mathrm{R}$ residues retained viral sensitivity to neuraminidase (oseltamivir and zanamivir) inhibitors [75]. These results were concordant with those of Cheung et al. [76] that reported the absence of resistant isolates in Japan and South Korea. Alterations in recep-
12

Intervirology 2022;65:1-16 DOI: $10.1159 / 000517057$
Yeo/Hoang/Duong/Nguyen/Tuong/ Azam/Sung/Park 


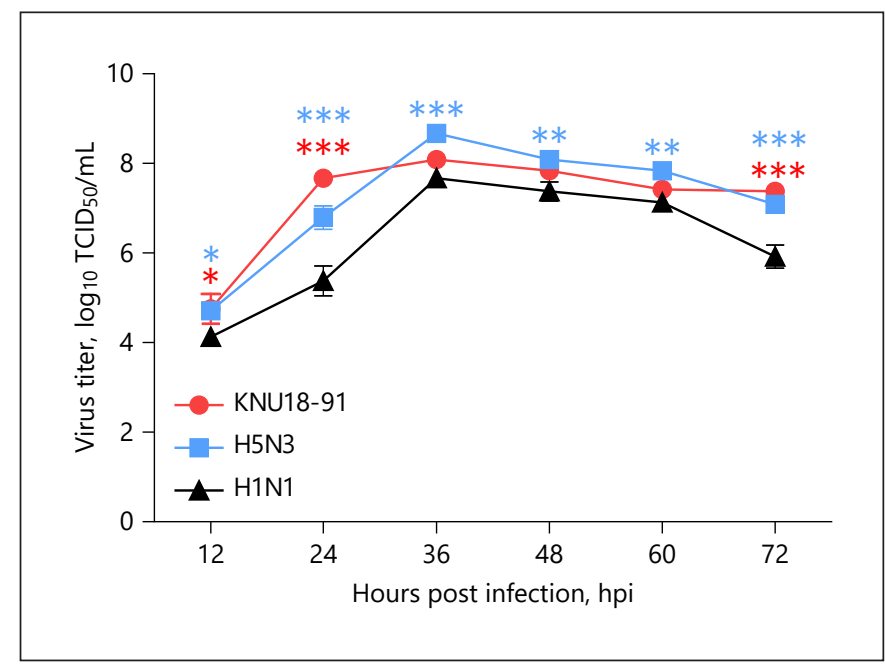

Fig. 3. In vitro growth kinetics of the KNU18-91 isolate in MDCK cells. The TCID50 assay was used to determine virus titer. MDCK cells were infected with viruses at $\mathrm{MOI}=0.01$. Supernatants were collected at $12 \mathrm{hpi}$ for $72 \mathrm{~h}$, and the TCID50 of each supernatant was measured by ELISA. The virus titers are presented as means \pm SDs $(n=3) .{ }^{*}, p<0.05 ;{ }^{* *}, p<0.01 ;{ }^{* * *}, p<0.001$. PA, polymerase acidic; NP, neuraminidase; HPAI, high-pathogenic avian influenza; MDCK, Madin-Darby canine kidney; TCID50, 50\% tissue culture infectious dose; MOI, multiplicity of infection; ELISA, enzyme-linked immunosorbent assay; SD, standard deviation; hpi, hour postinfection.

tor-binding sites change the binding preference from avian $\alpha-2,3$ to $\alpha-2,6$ sialic acid receptors, whereby our isolate had avian-specific (150A, 202E, 206L, 237G, 238Q, and 240G) conserved sequences [77, 78]. The 627E and 701D marker residues of the polymerase $\mathrm{PB} 2$ protein in a novel H5N3 isolate suggested that it was short of efficient polymerase adaptation to mammalian hosts [79].

Migratory birds from China breeding along the western coast of the Korean Peninsula may have had an isolate from the western province with high genetic diversity compared to old Korean isolates. Li et al. [9] reported recent $\mathrm{H} 5 \mathrm{~N} 3$ reassortments from migratory waterfowl and domestic ducks in China. In their study, 5 H5N3 genotypes were derived from reassortment in China during 2015-2018. Consistently, the HA gene of genotype 2, A/ duck/Chongqing/S4362/17/2017 (H5N3), corresponded to that of KNU18-91, and this strain provided the $M$ gene to the human strain H7N4, 2018. Interestingly, in the $M$ gene phylogenetic tree, KNU18-91 was separated from A/ duck/Chongqing/S4362/17/2017 (H5N3) (Fig. 1g), suggesting that a potential donor of the $M$ gene to KNU18-91 may induce human H7N4 in South Korea in the future [9].
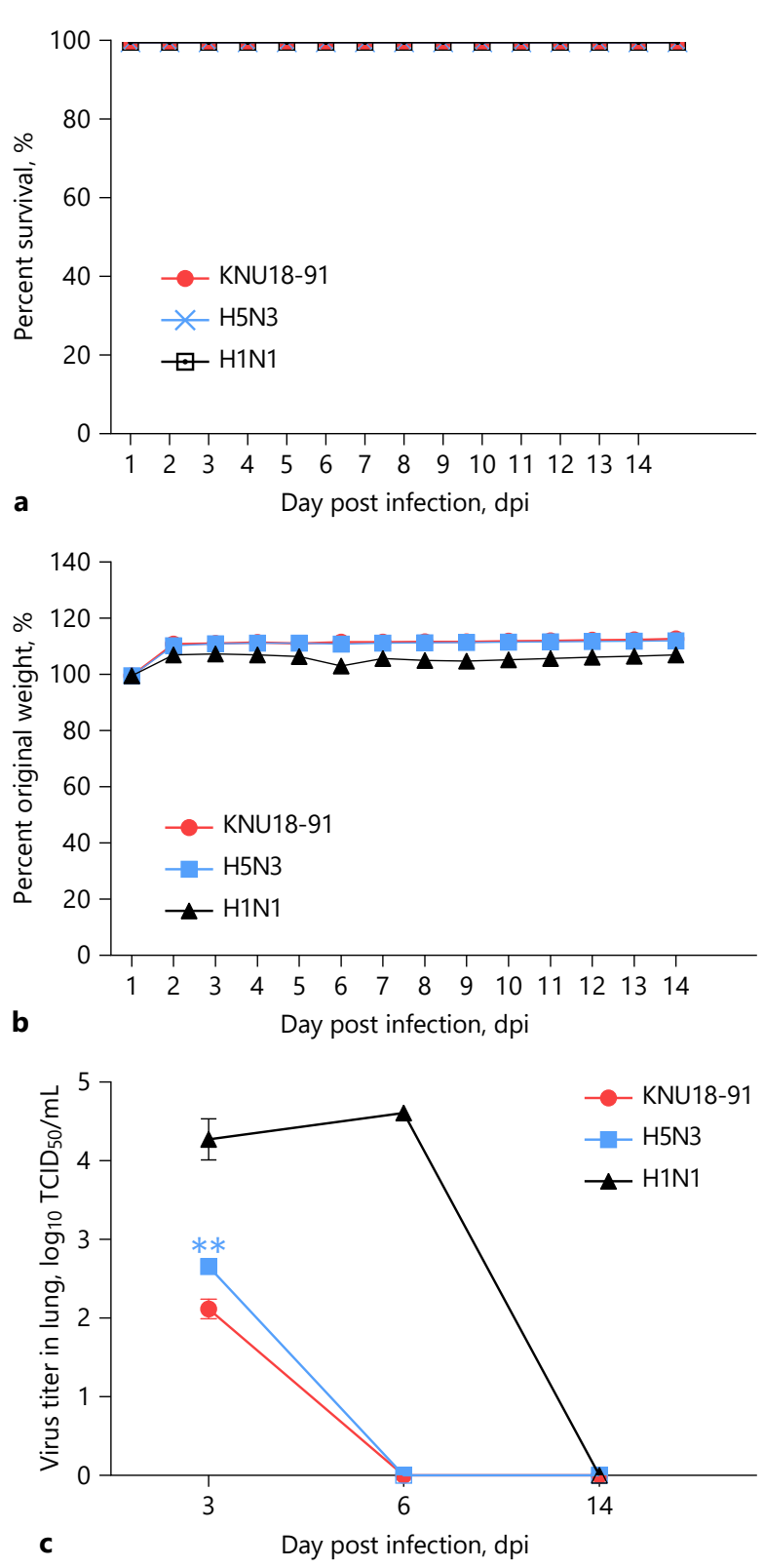

Fig. 4. Pathogenicity of KNU18-91 isolate in vivo. Female BALB/c mice were challenged with $10^{4} \mathrm{EID} 50 / \mathrm{mL}$ of virus by intranasal inoculation. The H1N1 subtype was used as the control. Mice survival rate (a) and body weight (b) were observed daily for $14 \mathrm{dpi}$. Body weight is shown as a percentage of that in mice before inoculation $(n=10)$. Mean virus titers in the lung of mice $(n=3)$ were determined at 3, 6, and $14 \mathrm{dpi}(\mathbf{c}){ }^{* *}, p<0.01$. EID50, 50\% egg infective dose; dpi, day postinfection. 
Our findings highlight the need for extensive surveillance at different locations in South Korea to predict new AIV strains and encourage the active surveillance in Jiangsu Province, China, to provide early warning for the direct dissemination potential of AIVs to nearby countries, including South Korea as the reassortment of preexisting LPAIVs by imported LPAIVs may eventually result in HPAIVs. Therefore, continuous LPAIV surveillance in South Korea is highly recommended.

In addition, the in vivo study in MDCK cells revealed that the KNU18-91 isolate had higher adaptation in a mammalian host than A/California/04/2009 (H1N1). However, it was lower than that of SBD/Korea/KNU SYG06/06 (H5N3). This may be due not only to the 13 mutations related to increasing virulence in mammalian hosts contained in KNU18-91 but also to the 8 different mutations between the KNU18-91 isolate and SBD/Korea/KNU SYG06/06 (H5N3) (Table 3) that exhibited the typical LPAIV phenotype, supporting the LPAIV characterization of the KNU18-91 (H5N3) isolate in this study.

Furthermore, KNU18-91 low adaptation in mice was revealed by the in vivo study, together with the LPAI H5N3 SBD/Korea/KNU SYG06/06; both H5N3 strains were detected at 3 dpi but not at 6 dpi. However, the virus titer in the lung for A/California/04/2009 (H1N1) was markedly higher than that of $\mathrm{H} 5 \mathrm{~N} 3$ strains at 3 and 6 dpi. The replication of the 3 viruses (KNU18-91 isolate, $\mathrm{H} 5 \mathrm{~N} 3$, and $\mathrm{H} 1 \mathrm{~N} 1$ ) in the mice lungs was absent at $14 \mathrm{dpi}$. According to $\mathrm{Gu}$ et al., A/California/04/2009 (H1N1) contains 3 out of mice amino acid sites related to increased mice adaptation [71], and thus, the A/California/04/2009 (H1N1) used in the present study was not a mice-adapted strain. Notably, none of the 3 viruses affected the survival rate, and there was no significant difference in body weight during infections. These results agree with those of Ilyushina et al. [80].

According to the antigenic characterization assay, influenza viruses are considered antigenically similar if their HA inhibition titers differ by 2 dilutions or less. However, circulating virus to differing by 32 -fold seem to be antigenically dissimilar [81]. In addition, Ohkawara et al. [82] reported that $\mathrm{H} 5$ viruses in the same clades showed HA inhibition titers differing by 2 -fold and 4 -fold, and by 8 -fold if belonging to different clades. In the present study, HA inhibition titers were consistent with those of previous studies, indicating antigenic differences between $\mathrm{H} 5$ viruses in clades 2.3.2.1 c and 2.3.4.4 [83]. It also demonstrated that the antigenicity of the KNU18-91 isolate differed from that of H5 HPAIVs and LPAIV A/spotbilled duck/Korea/KNU SYG06/2006 (H5N3) by 32-fold and 16 -fold, respectively.
The new H5N3 isolate studied here (KNU18-91) showed lower adaptation to mammalian cells than previous LPAI H5N3 viruses isolated in South Korea (A/spotbilled duck/Korea/KNU SYG06/2006; Fig. 3), although its replication ability in mice was similar (Fig. 4). In addition, the antigenicity of the KNU18-91 (H5N3) differed 16-fold from SBD/Korea/KNU SYG06/2006 (H5N3) according to HA inhibition results (Table 6). These results suggested a novel reassortant LPAIV H5N3 strain arose in South Korea in 2018.

In summary, a novel reassortant LPAIV H5N3 subtype emerged in South Korea in 2018 via novel multiple reassortments with Eurasian-derived AIVs. Because various wild birds have been directly or indirectly identified as a major source of HPAI viruses infecting poultry, further characterization of wild bird-derived H5 AIVs can provide the insights required for AIV outbreak prevention in poultry. Routine monitoring of influenza among domestic birds is also required for establishing infection control measures.

\section{Statement of Ethics}

This study was approved by the Animal Ethics Committee of the Wonkwang University (WKU19-64), and all methods were carried out in accordance with relevant guidelines and regulations.

\section{Conflict of Interest Statement}

The authors declare no conflict of interest.

\section{Funding Sources}

This research was supported by Priority Research Center Program by the National Research Foundation of Korea (NRF) funded by the Ministry of Education (NRF-2015R1A6A1A03032236) and the Bio \& Medical Technology Development Program of the NRF, and the MSIT (2018M3A9H4055768).

\section{Author Contributions}

Conceptualization: S.J.; methodology: V.T. and T.D.; software: V.T. and M.A.; validation: N.M., H.T., and H.W.; formal analysis: V.T. and T.D.; investigation: H.P. and S.J.; resources: H.W.; data curation: V.T. and T.D.; writing - original draft preparation: V.T., T.D., and M.A.; writing - review and editing: S.J.; visualization: V.T. and S.J.; supervision: S.J.; project administration: S.J.; and funding acquisition: H.P.
14

Intervirology 2022;65:1-16 DOI: $10.1159 / 000517057$
Yeo/Hoang/Duong/Nguyen/Tuong/ Azam/Sung/Park 


\section{References}

1 Fouchier RA, Munster V, Wallensten A, Bestebroer TM, Herfst S, Smith D, et al. Characterization of a novel influenza a virus hemagglutinin subtype (H16) obtained from black-headed gulls. J Virol. 2005;79:2814-22.

2 Tong S, Li Y, Rivailler P, Conrardy C, Castillo DA, Chen LM, et al. A distinct lineage of influenza A virus from bats. Proc Natl Acad Sci U S A. 2012;109:4269-74.

3 Tong S, Zhu X, Li Y, Shi M, Zhang J, Bourgeois $M$, et al. New world bats harbor diverse influenza A viruses. PLoS Pathog. 2013;9:e1003657.

4 Webster RG, Bean WJ, Gorman OT, Chambers TM, Kawaoka Y. Evolution and ecology of influenza A viruses. Microbiol Rev. 1992;56:15279.

5 Chen H, Li Y, Li Z, Shi J, Shinya K, Deng G, et al. Properties and dissemination of $\mathrm{H} 5 \mathrm{~N} 1$ viruses isolated during an influenza outbreak in migratory waterfowl in western China. J Virol. 2006;80:5976-83.

6 El-Shesheny R, Barman S, Feeroz MM, Hasan MK, Jones-Engel L, Franks J, et al. Genesis of Influenza $\mathrm{A}(\mathrm{H} 5 \mathrm{~N} 8)$ viruses. Emerging Infect Dis. 2017;23:1368-71.

7 Yoon H, Moon OK, Jeong W, Choi J, Kang YM, Ahn HY, et al. H5N8 highly pathogenic avian influenza in the Republic of Korea: epidemiology during the first wave, from January through July 2014. Osong Public Health Res Perspect. 2015;6:106-11.

8 Lee EK, Kang HM, Song BM, Lee YN, Heo GB, Lee HS, et al. Surveillance of avian influenza viruses in South Korea between 2012 and 2014. Virol J. 2017;14:54.

9 Li X, Cui P, Zeng X, Jiang Y, Li Y, Yang J, et al. Characterization of avian influenza $\mathrm{H} 5 \mathrm{~N} 3$ reassortants isolated from migratory waterfowl and domestic ducks in China from 2015 to 2018. Transbound Emerg Dis. 2019;66:2605-10.

10 Chen P, Xie JF, Lin Q, Zhao L, Zhang YH, Chen $\mathrm{HB}$, et al. A study of the relationship between human infection with avian influenza a (H5N6) and environmental avian influenza viruses in Fujian, China. BMC Infect Dis. 2019;19:762.

11 Killian ML. Hemagglutination-inhibition assay for influenza virus subtype identification and the detection and quantitation of serum antibodies to influenza virus. Methods Mol Biol. 2014;1161:11-25.

12 World Health Organization. WHO information for the molecular detection of influenza viruses. Geneva, Switzerland: World Health Organization; 2017. Available from: http://www. who.int/influenza/gisrs_laboratory/molecular_diagnosis/en.

13 Hebert PD, Stoeckle MY, Zemlak TS, Francis CM. Identification of birds through DNA barcodes. PLoS Biol. 2004;2:e312-63.

14 Ambardar S, Gupta R, Trakroo D, Lal R, Vakhlu J. High throughput sequencing: an overview of sequencing chemistry. Indian J Microbiol. 2016;56:394-404.
15 Hackl T, Hedrich R, Schultz J, Förster F. Proovread: large-scale high-accuracy PacBio correction through iterative short read consensus. Bioinformatics. 2014;30:3004-11.

16 Tamura K, Stecher G, Peterson D, Filipski A, Kumar S. MEGA6: molecular evolutionary genetics analysis version 6.0. Mol Biol Evol. 2013; 30:2725-9.

17 World Health Organization. Manual for the laboratory diagnosis and virological surveillance of influenza. Geneva: World Health Organization; 2011. p. xii, 139.

18 Reed LJ, Muench H. A simple method of estimating fifty percent endpoints. Am J Hyg. 1938;27:493497

19 Jimenez-Bluhm P, Karlsson EA, Ciuoderis KA, Cortez V, Marvin SA, Hamilton-West C, et al. Avian H11 influenza virus isolated from domestic poultry in a Colombian live animal market. Emerg Microbes Infect. 2016;5(12):e121.

20 The University of IOWA. Available from: https: //animal.research.uiowa.edu/iacuc-guidelines-anesthesia.

21 Kaufmann L, Syedbasha M, Vogt D, Hollenstein Y, Hartmann J, Linnik JE, et al. An optimized hemagglutination inhibition (HI) assay to quantify influenza-specific antibody titers. J Vis Exp. 2017;(130):55833.

22 Lee JH, Kwon HM, Sung HW. Molecular characterization of an $\mathrm{H} 5 \mathrm{~N} 3$ influenza virus isolated from spot-billed duck. Korean J Poult Sci. 2013; 40(3):243-52

23 Lee MS, Chen LH, Chen YP, Liu YP, Li WC, Lin $\mathrm{YL}$, et al. Highly pathogenic avian influenza viruses $\mathrm{H} 5 \mathrm{~N} 2, \mathrm{H} 5 \mathrm{~N} 3$, and $\mathrm{H} 5 \mathrm{~N} 8$ in Taiwan in 2015. Vet Microbiol. 2016;187:50-7.

24 Leung BW, Chen H, Brownlee GG. Correlation between polymerase activity and pathogenicity in two duck H5N1 influenza viruses suggests that the polymerase contributes to pathogenicity. Virology. 2010;401:96-106.

25 Shaw M, Cooper L, Xu X, Thompson W, Krauss S, Guan Y, et al. Molecular changes associated with the transmission of avian influenza a H5N1 and H9N2 viruses to humans. J Med Virol. 2002;66:107-14.

26 Chen H, Bright RA, Subbarao K, Smith C, Cox NJ, Katz JM, et al. Polygenic virulence factors involved in pathogenesis of 1997 Hong Kong $\mathrm{H} 5 \mathrm{~N} 1$ influenza viruses in mice. Virus Res. 2007;128:159-63.

27 Lycett SJ, Ward MJ, Lewis FI, Poon AF, Kosakovsky Pond SL, Brown AJ. Detection of mammalian virulence determinants in highly pathogenic avian influenza $\mathrm{H} 5 \mathrm{~N} 1$ viruses: multivariate analysis of published data. J Virol. 2009;83: 9901-10.

28 Katz JM, Lu X, Tumpey TM, Smith CB, Shaw MW, Subbarao K. Molecular correlates of influenza A H5N1 virus pathogenesis in mice. J Virol. 2000;74:10807-10.

29 Lee MS, Deng MC, Lin YJ, Chang CY, Shieh $\mathrm{HK}$, Shiau JZ, et al. Characterization of an H5N1 avian influenza virus from Taiwan. Vet Microbiol. 2007;124:193-201.
30 Govorkova EA, Rehg JE, Krauss S, Yen HL, Guan Y, Peiris M, et al. Lethality to ferrets of $\mathrm{H} 5 \mathrm{~N} 1$ influenza viruses isolated from humans and poultry in 2004. J Virol. 2005;79:2191-8.

31 Salomon R, Franks J, Govorkova EA, Ilyushina NA, Yen HL, Hulse-Post DJ, et al. The polymerase complex genes contribute to the high virulence of the human $\mathrm{H} 5 \mathrm{~N} 1$ influenza virus isolate A/Vietnam/1203/04. J Exp Med. 2006; 203:689-97.

32 Chen GW, Kuo SM, Yang SL, Gong YN, Hsiao MR, Liu YC, et al. Genomic signatures for Avian H7N9 viruses adapting to humans. PLoS One. 2016;11:e0148432.

33 Mehle A, Doudna JA. Adaptive strategies of the influenza virus polymerase for replication in humans. Proc Natl Acad Sci U S A. 2009;106: 21312-6.

34 Finkelstein DB, Mukatira S, Mehta PK, Obenauer JC, Su X, Webster RG, et al. Persistent host markers in pandemic and $\mathrm{H} 5 \mathrm{~N} 1$ influenza viruses. J Virol. 2007;81:10292-9.

35 Gabriel G, Abram M, Keiner B, Wagner R, Klenk HD, Stech J. Differential polymerase activity in avian and mammalian cells determines host range of influenza virus. J Virol. 2007;81: 9601-4.

36 Gabriel G, Dauber B, Wolff T, Planz O, Klenk $\mathrm{HD}$, Stech J. The viral polymerase mediates adaptation of an avian influenza virus to a mammalian host. Proc Natl Acad Sci U S A. 2005; 102:18590-5.

37 Conenello GM, Zamarin D, Perrone LA, Tumpey T, Palese P. A single mutation in the PB1-F2 of H5N1 (HK/97) and 1918 influenza A viruses contributes to increased virulence. PLoS Pathog. 2007;3:1414-21.

38 Kamal RP, Alymova IV, York IA. Evolution and virulence of influenza A virus protein $\mathrm{PB} 1$ F2. Int J Mol Sci. 2018;19(1):96.

39 Yamayoshi S, Yamada S, Fukuyama S, Murakami S, Zhao D, Uraki R, et al. Virulence-affecting amino acid changes in the PA protein of H7N9 influenza A viruses. J Virol. 2014;88:3127-34.

40 Yamaji R, Yamada S, Le MQ, Ito M, SakaiTagawa Y, Kawaoka Y. Mammalian adaptive mutations of the PA protein of highly pathogenic avian H5N1 influenza virus. J Virol. 2015; 89:4117-25.

41 Xu G, Zhang X, Gao W, Wang C, Wang J, Sun $\mathrm{H}$, et al. Prevailing PA mutation K356R in Avian influenza H9N2 virus increases mammalian replication and pathogenicity. J Virol. 2016;90: 8105-14.

42 Wang W, Lu B, Zhou H, Suguitan AL, Cheng $\mathrm{X}$, Subbarao K, et al. Glycosylation at $158 \mathrm{~N}$ of the hemagglutinin protein and receptor binding specificity synergistically affect the antigenicity and immunogenicity of a live attenuated H5N1 A/Vietnam/1203/2004 vaccine virus in ferrets. J Virol. 2010;84:6570-7.

43 Yu Z, Cheng K, Xin Y, Sun W, Li X, Huang J, et al. Multiple amino acid substitutions involved in the adaptation of $\mathrm{H} 6 \mathrm{~N} 1$ avian influenza virus in mice. Vet Microbiol. 2014;174:316-21. 
44 Chen L, Wang C, Luo J, Li M, Liu H, Zhao N, et al. Amino acid substitution K470R in the nucleoprotein increases the virulence of $\mathrm{H} 5 \mathrm{~N} 1 \mathrm{in}$ fluenza A virus in mammals. Front Microbiol. 2017;8:1308.

45 Zhou HB, Yu ZJ, Hu Y, Tu JG, Zou W, Peng YP, et al. The special neuraminidase Stalk-Motif responsible for increased virulence and pathogenesis of $\mathrm{H} 5 \mathrm{~N} 1$ influenza A virus. PLoS One. 2009;4.

46 Eshaghi A, Shalhoub S, Rosenfeld P, Li A, Higgins RR, Stogios PJ, et al. Multiple influenza A $(\mathrm{H} 3 \mathrm{~N} 2)$ mutations conferring resistance to neuraminidase inhibitors in a bone marrow transplant recipient. Antimicrob Agents Chemother. 2014;58:7188-97.

47 Peng X, Wu H, Peng X, Wu X, Cheng L, Liu F, et al. Amino acid substitutions occurring during adaptation of an emergent H5N6 avian influenza virus to mammals. Arch Virol. 2016; 161:1665-70.

48 DeVries A, Wotton J, Lees C, Boxrud D, Uyeki T, Lynfield R. Neuraminidase H275Y and hemagglutinin D222G mutations in a fatal case of 2009 pandemic influenza A (H1N1) virus infection. Influenza Other Respir Viruses. 2012;6: e85-8.

49 Subbarao K, Shaw MW. Molecular aspects of avian influenza (H5N1) viruses isolated from humans. Rev Med Virol. 2000;10:337-48.

50 Kaewborisuth C, Kaplan B, Zanin M, Finkelstein D, Webby RJ, Lekcharoensuk P. G45R on nonstructural protein 1 of influenza A virus contributes to virulence by increasing the expression of proinflammatory cytokines in mice. Arch Virol. 2017;162:45-55.

51 Kanrai P, Mostafa A, Madhugiri R, Lechner M, Wilk E, Schughart K, et al. Identification of specific residues in avian influenza A virus NS1 that enhance viral replication and pathogenicity in mammalian systems. J Gen Virol. 2016; 97:2135-48.

52 Li W, Wang G, Zhang H, Xin G, Zhang D, Zeng $\mathrm{J}$, et al. Effects of NS1 variants of H5N1 influenza virus on interferon induction, TNFalpha response and p53 activity. Cell Mol Immunol. 2010;7:235-42.

53 Seo SH, Hoffmann E, Webster RG. Lethal H5N1 influenza viruses escape host anti-viral cytokine responses. Nat Med. 2002;8:950-4.

54 Kuo RL, Krug RM. Influenza A virus polymerase is an integral component of the CPSF30NS1A protein complex in infected cells. J Virol. 2009;83:1611-6.

55 Thomas M, Kranjec C, Nagasaka K, Matlashewski G, Banks L. Analysis of the PDZ binding specificities of influenza A virus NS1 proteins. Virol J. 2011;8:25.

56 Kongchanagul A, Suptawiwat O, Kanrai P, Uiprasertkul M, Puthavathana P, Auewarakul P. Positive selection at the receptor-binding site of haemagglutinin $\mathrm{H} 5$ in viral sequences derived from human tissues. J Gen Virol. 2008;89: 1805-10.

57 Watanabe Y, Ibrahim MS, Ellakany HF, Kawashita N, Mizuike R, Hiramatsu H, et al. Ac- quisition of human-type receptor binding specificity by new $\mathrm{H} 5 \mathrm{~N} 1$ influenza virus sublineages during their emergence in birds in Egypt. PLoS Pathog. 2011;7:e1002068.

58 Herfst S, Schrauwen EJ, Linster M, Chutinimitkul S, de Wit E, Munster VJ, et al. Airborne transmission of influenza $\mathrm{A} / \mathrm{H} 5 \mathrm{~N} 1$ virus between ferrets. Science. 2012;336:1534-41.

59 Yen HL, Aldridge JR, Boon AC, Ilyushina NA, Salomon R, Hulse-Post DJ, et al. Changes in H5N1 influenza virus hemagglutinin receptor binding domain affect systemic spread. Proc Natl Acad Sci U S A. 2009;106:286-91.

60 Imai M, Watanabe T, Hatta M, Das SC, Ozawa $\mathrm{M}$, Shinya K, et al. Experimental adaptation of an influenza $\mathrm{H} 5 \mathrm{HA}$ confers respiratory droplet transmission to a reassortant $\mathrm{H} 5 \mathrm{HA} / \mathrm{H} 1 \mathrm{~N} 1 \mathrm{vi}-$ rus in ferrets. Nature. 2012;486:420-8.

61 Boltz DA, Douangngeun B, Phommachanh P Sinthasak S, Mondry R, Obert C, et al. Emergence of $\mathrm{H} 5 \mathrm{~N} 1$ avian influenza viruses with reduced sensitivity to neuraminidase inhibitors and novel reassortants in Lao People's Democratic Republic. J Gen Virol. 2010;91:949-59.

62 Ilyushina NA, Seiler JP, Rehg JE, Webster RG Govorkova EA. Effect of neuraminidase inhibitor-resistant mutations on pathogenicity of clade $2.2 \mathrm{~A} /$ Turkey/15/06 (H5N1) influenza virus in ferrets. PLoS Pathog. 2010;6:e1000933.

63 Baek YH, Song MS, Lee EY, Kim YI, Kim EH, Park SJ, et al. Profiling and characterization of influenza virus N1 strains potentially resistant to multiple neuraminidase inhibitors. J Virol. 2015;89:287-99.

64 Mai TQL, Heiman FLW, Hien DN, Walter T, Phuong VMH, Cuong DV, et al. Influenza A H5N1 clade 2.3.4 virus with a different antiviral susceptibility profile replaced clade 1 virus in humans in Northern Vietnam. PLoS One. 2008;3.

65 Naughtin M, Dyason JC, Mardy S, Sorn S, von Itzstein M, Buchy P. Neuraminidase inhibitor sensitivity and receptor-binding specificity of cambodian clade 1 highly pathogenic $\mathrm{H} 5 \mathrm{~N} 1$ influenza virus. Antimicrob Agents Chemother. 2011:55:2004-10.

66 Hurt AC, Holien JK, Barr IG. In vitro generation of neuraminidase inhibitor resistance in $\mathrm{A}(\mathrm{H} 5 \mathrm{~N} 1)$ influenza viruses. Antimicrob Agents Chemother. 2009;53:4433-40.

67 Hurt AC, Selleck P, Komadina N, Shaw R, Brown L, Barr IG. Susceptibility of highly pathogenic $\mathrm{A}(\mathrm{H} 5 \mathrm{~N} 1)$ avian influenza viruses to the neuraminidase inhibitors and adamantanes. Antiviral Res. 2007;73:228-31.

$68 \mathrm{Hu}$ Y, Musharrafieh R, Ma C, Zhang J, Smee DF, DeGrado WF, et al. An M2-V27A channel blocker demonstrates potent in vitro and in vivo antiviral activities against amantadinesensitive and -resistant influenza A viruses. Antiviral Res. 2017;140:45-54.

69 Cady SD, Luo W, Hu F, Hong M. Structure and function of the influenza A M2 proton channel. Biochemistry. 2009;48:7356-64.

70 Wang J, Wu Y, Ma C, Fiorin G, Wang J, Pinto $\mathrm{LH}$, et al. Structure and inhibition of the drug- resistant S31N mutant of the M2 ion channel of influenza A virus. Proc Natl Acad Sci U S A. 2013;110:1315-20.

71 Gu M, Zhao G, Zhao K, Zhong L, Huang J, Wan $\mathrm{H}$, et al. Novel variants of Clade 2.3.4 highly pathogenic avian influenza $\mathrm{A}(\mathrm{H} 5 \mathrm{~N} 1)$ viruses, China. Emerging Infect Dis. 2013;19:2021-4.

72 Jeong J, Kang HM, Lee EK, Song BM, Kwon YK, Kim HR, et al. Highly pathogenic avian influenza virus (H5N8) in domestic poultry and its relationship with migratory birds in South Korea during 2014. Vet Microbiol. 2014;173:249-57.

73 Kang HM, Lee EK, Song BM, Jeong J, Choi JG, Jeong J, et al. Novel reassortant influenza A(H5N8) viruses among inoculated domestic and wild ducks, South Korea, 2014. Emerging Infect Dis. 2015;21:298-304.

74 Matrosovich M, Zhou N, Kawaoka Y, Webster $\mathrm{R}$. The surface glycoproteins of H5 influenza viruses isolated from humans, chickens, and wild aquatic birds have distinguishable properties. J Virol. 1999;73:1146-55.

75 Choi WS, Jeong JH, Kwon JJ, Ahn SJ, Lloren KKS, Kwon HI, et al. Screening for neuraminidase inhibitor resistance markers among avian influenza viruses of the $\mathrm{N} 4, \mathrm{~N} 5, \mathrm{~N} 6$, and $\mathrm{N} 8$ neuraminidase subtypes. J Virol. 2018;92.

76 Cheung CL, Rayner JM, Smith GJ, Wang P, Naipospos TS, Zhang J, et al. Distribution of amantadine-resistant $\mathrm{H} 5 \mathrm{~N} 1$ avian influenza variants in Asia. J Infect Dis. 2006;193:1626-9.

77 Tumpey TM, Maines TR, Van Hoeven N, Glaser L, Solórzano A, Pappas C, et al. A two-amino acid change in the hemagglutinin of the 1,918 influenza virus abolishes transmission. Science. 2007;315:655-9.

78 Yamada S, Suzuki Y, Suzuki T, Le MQ, Nidom CA, Sakai-Tagawa Y, et al. Haemagglutinin mutations responsible for the binding of $\mathrm{H} 5 \mathrm{~N} 1$ influenza A viruses to human-type receptors. Nature. 2006;444:378-82.

79 Aggarwal S, Dewhurst S, Takimoto T, Kim B. Biochemical Impact of the Host Adaptationassociated PB2 E627K mutation on the temperature-dependent RNA synthesis kinetics of influenza A virus polymerase complex. J Biol Chem. 2011;286:34504-13.

80 Ilyushina NA, Khalenkov AM, Seiler JP, Forrest $\mathrm{HL}$, Bovin NV, Marjuki H, et al. Adaptation of pandemic $\mathrm{H} 1 \mathrm{~N} 1$ influenza viruses in mice. J Virol. 2010 Sep;84(17):8607-16. Available from: https: //www.cdc.gov/flu/about/professionals/ antigenic.htm.

81 https: //www.cdc.gov/flu/about/professionals/ antigenic.htm.

82 Ohkawara A, Okamatsu M, Ozawa M, Chu $\mathrm{DH}$, Nguyen LT, Hiono T, et al. Antigenic diversity of $\mathrm{H} 5$ highly pathogenic avian influenza viruses of clade 2.3. 4.4 isolated in Asia. Microbiol Immunol. 2017;61:149-58.

83 Nguyen LT, Firestone SM, Stevenson MA, Young ND, Sims LD, Chu DH, et al. A systematic study towards evolutionary and epidemiological dynamics of currently predominant $\mathrm{H} 5$ highly pathogenic avian influenza viruses in Vietnam. Sci Rep. 2019;9:7723. 